\title{
Clinicopathological correlates of hyperparathyroidism
}

\author{
Kai Duan, ${ }^{1,2}$ Karen Gomez Hernandez, ${ }^{3,4}$ Ozgur Mete ${ }^{1,2,3}$
}

\begin{abstract}
${ }^{1}$ Department of Pathology, University Health Network, Toronto, Ontario, Canada ${ }^{2}$ Department of Laboratory Medicine and Pathobiology, University of Toronto, Toronto, Ontario, Canada ${ }^{3}$ Endocrine Oncology Site Group, Princess Margaret Cancer Centre, Toronto, Ontario, Canada ${ }^{4}$ Department of Medicine, University Health Network Toronto, Ontario, Canada
\end{abstract}

\section{Correspondence to} Dr Ozgur Mete, Department of Laboratory Medicine and Pathobiology, University of Toronto; Department of Pathology, University Health Network, 200 Elizabeth Street, 11th floor, University Health Network: Department of Pathology, Toronto, ON M5G 2C4 Canada; ozgur.mete2@uhn.ca

Received 18 June 2015 Accepted 20 June 2015 Published Online First 10 July 2015

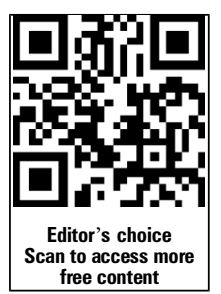

\begin{abstract}
Hyperparathyroidism is a common endocrine disorder with potential complications on the skeletal, renal, neurocognitive and cardiovascular systems. While most cases $(95 \%)$ occur sporadically, about $5 \%$ are associated with a hereditary syndrome: multiple endocrine neoplasia syndromes (MEN-1, MEN-2A, MEN-4), hyperparathyroidism-jaw tumour syndrome (HPT-JT), familial hypocalciuric hypercalcaemia $(\mathrm{FHH}-1, \mathrm{FHH}-2$, $\mathrm{FHH}-3$ ), familial hypercalciuric hypercalcaemia, neonatal severe hyperparathyroidism and isolated familial hyperparathyroidism. Recently, molecular mechanisms underlying possible tumour suppressor genes (MEN1, CDC73/HRPT2, CDKIS, APC, SFRPS, GSK3 $\beta$, RASSF1A, HIC1, RIZ1, WT1, CaSR, GNA11, AP2S1) and protooncogenes (CCND1/PRAD1, RET, ZFX, CTNNB 1, EZH2) have been uncovered in the pathogenesis of hyperparathyroidism. While bi-allelic inactivation of CDC73/HRPT2 seems unique to parathyroid malignancy, aberrant activation of cyclin D1 and Wnt/ $\beta$-catenin signalling has been reported in benign and malignant parathyroid tumours. Clinicopathological correlates of primary hyperparathyroidism include parathyroid adenoma (80-85\%), hyperplasia (10-15\%) and carcinoma $(<1-5 \%)$. Secondary hyperparathyroidism generally presents with diffuse parathyroid hyperplasia, whereas tertiary hyperparathyroidism reflects the emergence of autonomous parathyroid hormone (PTH)-producing neoplasm(s) from secondary parathyroid hyperplasia. Surgical resection of abnormal parathyroid tissue remains the only curative treatment in primary hyperparathyroidism, and parathyroidectomy specimens are frequently encountered in this setting. Clinical and biochemical features, including intraoperative PTH levels, number, weight and size of the affected parathyroid gland(s), are crucial parameters to consider when rendering an accurate diagnosis of parathyroid proliferations. This review provides an update on the expanding knowledge of hyperparathyroidism and highlights the clinicopathological correlations of this prevalent disease.
\end{abstract}

\section{INTRODUCTION}

Hyperparathyroidism (HPT) is a common endocrine disorder characterised by oversecretion of parathyroid hormone (PTH), which may be autonomous (independent of serum calcium levels) or the result of a physiological stimulus. ${ }^{1-11}$ Our understanding of this disease has progressed substantially over the past decade, with advancements made in biochemical, radiological and molecular testing. ${ }^{1} 31213$ Early detection is crucial to prevent complications from uncontrolled HPT, affecting the kidneys (ie, nephrolithiasis or nephrocalcinosis) and bones (ie, osteoporosis, osteitis fibrosa cystica). ${ }^{4} \quad \begin{array}{llll}6 & 7 & 14-19 & \text { Furthermore, neurocognitive }\end{array}$ dysfunction and cardiovascular morbidity and mortality appear to be increased in patients with overt HPT, although the nature and reversibility of these effects remains less evident. ${ }^{4} 1415$ 20-25

HPT is generally divided into three types: primary (autonomous HPT), secondary (HPT that results from a chronic stimulus causing PTH secretion) and tertiary (emergence of autonomous HPT in refractory secondary HPT). ${ }^{1-9}$ Primary HPT is currently the most common cause of hypercalcaemia, with an annual incidence ranging from 34 to 120 cases per $100000 .^{4}{ }^{7} 1426-28$ While most cases are sporadic (95\%), about 5\% present with a hereditary syndrome: multiple endocrine neoplasia syndromes (MEN-1, MEN-4, MEN-2A), hyperparathyroidism-jaw tumour syndrome (HPT-JT), familial hypocalciuric hypercalcaemia (FHH-1, FHH-2, FHH-3), familial hypercalciuric hypercalcaemia, neonatal severe HPT and isolated familial HPT. ${ }^{4} 729-33$

Surgical resection of abnormal 'hyperfunctioning' parathyroid gland(s) remains the only curative treatment for primary HPT. ${ }^{1472934-37}$ Thus, parathyroidectomy specimens are frequently encountered in this setting. ${ }^{3}{ }^{38-45}$ Clinicopathological correlates of primary HPT include parathyroid adenoma (80-85\%), hyperplasia (10-15\%) and carcinoma $(<1-5 \%) .{ }^{4} 7383941424446-49$ Secondary HPT typically presents with diffuse parathyroid hyperplasia, whereas tertiary HPT reflects the emergence of autonomous PTH-producing adenoma or rarely carcinoma from a background of secondary hyperplasia. ${ }^{711424446}$ Accurate subtyping is important for treatment decision-making and requires a thorough integration of pathological features with clinical, biochemical, radiological and intraoperative findings. ${ }^{1} 4742$ 49-51 This review provides an update on the evolving knowledge of HPT and highlights the clinicopathological correlations of this important disease.

\section{CLINICAL AND BIOCHEMICAL FEATURES}

Clinically, sporadic primary HPT can present at any age, with an increased incidence in postmenopausal women. ${ }^{4} 730425253$ A wide spectrum of clinical manifestations can be encountered, depending on the duration and degree of PTH oversecretion and resultant hypercalcaemia (tables 1 and 2). ${ }^{4671214}$ In the past, symptomatic disease was the most common presentation, prompting the 'classic' description of 'stones' (ie, nephrolithiasis), 'bones' (ie, osteitis fibrosis cystica) and 'groans' (ie, constipation, ileus). ${ }^{46121415}$ However, with the advent of routine serum calcium testing, most cases (70-80\%) are now diagnosed incidentally, in the 'asymptomatic' form. ${ }^{72} 14$ The natural progression from asymptomatic to symptomatic disease remains unclear at this time. ${ }^{4712}{ }^{14}$ However, even its 'asymptomatic' form, HPT is associated with 
Table 1 Brief overview of hyperparathyroidism

\begin{tabular}{|c|c|c|c|}
\hline Syndrome & Primary hyperparathyroidism & Secondary hyperparathyroidism* & Tertiary hyperparathyroidism \\
\hline Definition & $\begin{array}{l}\text { Autonomous PTH oversecretion from } \\
\text { abnormal parathyroid gland(s) }\end{array}$ & $\begin{array}{l}\text { Pathophysiological PTH oversecretion in response } \\
\text { to a chronic stimulus that is usually extracellular } \\
\text { hypocalcaemia }\end{array}$ & $\begin{array}{l}\text { Emergence of autonomous PTH oversecretion (neoplastic } \\
\text { transformation) from secondary parathyroid hyperplasia } \\
\text { usually occurring in the setting of long-standing CKD and } \\
\text { after renal transplant }\end{array}$ \\
\hline $\begin{array}{l}\text { Clinical } \\
\text { manifestations }\end{array}$ & $\begin{array}{l}\text { Often asymptomatic; more } \\
\text { symptomatict in malignant HPT }\end{array}$ & $\begin{array}{l}\text { May be symptomatict, especially in patients with } \\
\text { longstanding chronic kidney disease }\end{array}$ & May be symptomatict; often refractory to medical therapy \\
\hline Biochemistry & $\begin{array}{l}\text { Mild hypercalcaemia with elevated } \\
\text { PTH levels; more severe findings in } \\
\text { malignant HPT }\end{array}$ & $\begin{array}{l}\text { Normocalcemia or hypocalcaemia with elevated } \\
\text { PTH levels; in patients with CKD: } \\
\text { hyperphosphatemia, decreased 1,25-(OH)2D3 }\end{array}$ & Hypercalcaemia and elevated PTH levels \\
\hline Radiology & $\begin{array}{l}\text { Single-gland parathyroid disease } \\
(80-85 \%) \text { or multigland disease } \\
(10-15 \%)\end{array}$ & Multigland parathyroid disease & Multigland parathyroid disease \\
\hline Pathology & $\begin{array}{l}\text { Parathyroid adenoma }(80-85 \%) \text {, } \\
\text { hyperplasia }(10-15 \%) \text { and/or } \\
\text { carcinoma }(<1-5 \%)\end{array}$ & Parathyroid hyperplasia & $\begin{array}{l}\text { Autonomous nodular proliferation (often adenoma, rarely } \\
\text { carcinoma) in a background of parathyroid hyperplasia }\end{array}$ \\
\hline Treatment & Surgery & $\begin{array}{l}\text { Generally medical therapy, although surgery may } \\
\text { be indicated in some patients with chronic } \\
\text { kidney disease }\end{array}$ & Often surgery, given resistance to medical therapy \\
\hline
\end{tabular}

*Secondary causes of hyperparathyroidism include chronic kidney disease (most classic), vitamin D deficiency and calcium malabsorption.

tSigns and symptoms include bone pain, osteoporosis, kidney stones and neuropsychiatric manifestations. Additionally, patients with hyperparathyroidism due to chronic kidney disease may experience pruritus and calcification of soft tissues and vessels.

CKD, chronic kidney disease; HPT, hyperparathyroidism; PTH, parathyroid hormone.

potential morbidities, including decreased trabecular/cortical bone density and clinically 'silent' nephrolithiasis/nephrocalcinosis, which can be detected radiographically. ${ }^{6} 12 \quad 14$ 16-19 54-62 In light of these findings, all cases of incidentally detected hypercalcaemia merit additional investigations, including 'intact' serum PTH measurement, to clarify its aetiology (PTH dependent vs PTH independent). ${ }^{4} 67$ Other commonly described symptoms in HPT are associated with hypercalcaemia (ie, weakness, easy fatigability, anxiety, cognitive impairment). ${ }^{471214152054}$
Gastrointestinal manifestations are almost never reported in the modern presentation of primary HPT. ${ }^{6} 14156364$

Biochemically, mild hypercalcaemia (usually within $0.25 \mathrm{mmol} / \mathrm{L}$ of normal range) is often the first finding in sporadic primary HPT. ${ }^{4} 6765$ Typically, urinary calciuria is normal or increased although it may be low in individuals with concomitant thiazide or lithium use. ${ }^{66} 67$ A persistently low calciuria after thiazide or lithium discontinuation should raise the possibility of FHH. A normocalcemic variant of primary HPT,

Table 2 Clinicopathological correlates of primary hyperparathyroidism

\begin{tabular}{|c|c|c|c|}
\hline Diagnosis & Parathyroid hyperplasia (multigland disease) & $\begin{array}{l}\text { Parathyroid adenoma (single-gland } \\
\text { disease)* }\end{array}$ & $\begin{array}{l}\text { Parathyroid carcinoma (single-gland } \\
\text { disease)* }\end{array}$ \\
\hline Frequency & 10-15\% & 80-85\% & $<1-5 \%$ \\
\hline Onset & $\begin{array}{l}\text { Variable, but in familial forms earlier than single-gland } \\
\text { disease }\end{array}$ & Usually after age 50 & $\begin{array}{l}\text { Usually after age } 50 \text {, except in HPT-JT or } \\
\text { familial isolated HPT }\end{array}$ \\
\hline Clinical features & $\begin{array}{l}\text { Variable symptomst, depending on the familial syndrome } \\
\text { ( } 25 \% \text { of cases). Consider family history of hypercalcaemia } \\
\text { (FHH) and/or other familial endocrine disorders (MEN) }\end{array}$ & $\begin{array}{l}\text { Often asymptomatic, Although large } \\
\text { adenomas can present with overt HPT } \\
\text { symptomst }\end{array}$ & $\begin{array}{l}\text { Severe HPT symptomst, palpable neck mass, } \\
\text { jaw tumour (HPT-JT) and/or hypercalcemic } \\
\text { crisis with neurological manifestations }\end{array}$ \\
\hline $\begin{array}{l}\text { Biochemical } \\
\text { features }\end{array}$ & $\begin{array}{l}\text { Variable biochemistry profile (mild-to-severe hypercalcaemia } \\
\text { and HPT) depending on the genetic syndrome. } \\
\text { In hypocalciuria, consider FHH }\end{array}$ & $\begin{array}{l}\text { Often mild hypercalcaemia with } \\
\text { mild-to-moderate HPT, although more } \\
\text { severe features are seen in large adenomas }\end{array}$ & $\begin{array}{l}\text { Severe hypercalcaemia with marked } \\
\text { elevations of PTH }\end{array}$ \\
\hline $\begin{array}{l}\text { Radiological } \\
\text { features }\end{array}$ & $\begin{array}{l}\text { Multigland disease may be detected with imaging but } \\
\text { usually localising studies are more helpful in the setting of } \\
\text { recurrent disease after most of the abnormal parathyroid } \\
\text { tissue has already been removed. }\end{array}$ & $\begin{array}{l}\text { Single-gland disease on sestamibi, US and/ } \\
\text { or CT scan }\end{array}$ & $\begin{array}{l}\text { Single-gland disease, } \pm \text { distant metastasis or } \\
\text { local invasion }\end{array}$ \\
\hline Treatment & $\begin{array}{l}\text { Four gland parathyroid exploration followed by total or } \\
\text { subtotal parathyroidectomy }\end{array}$ & $\begin{array}{l}\text { Minimally invasive parathyroidectomy with } \\
\text { intraoperative PTH measurements }\end{array}$ & $\begin{array}{l}\text { Oncological surgical approach, including at } \\
\text { least 'en bloc' resection }\end{array}$ \\
\hline $\begin{array}{l}\text { Special } \\
\text { considerations }\end{array}$ & $\begin{array}{l}\text { Genetic testing should be considered, unless identifiable } \\
\text { cause such as chronic kidney disease }\end{array}$ & $\begin{array}{l}\text { True single-gland disease is usually } \\
\text { sporadic }\end{array}$ & $\begin{array}{l}\text { Consider genetic testing, in carcinomas with } \\
\text { loss of parafibromin }\end{array}$ \\
\hline Prognosis & $\begin{array}{l}\text { Risk of recurrent and/or persistent disease after surgery, } \\
\text { especially in individuals with } \mathrm{FHH}-1\end{array}$ & Often cured after surgery & $\begin{array}{l}\text { High risk of locoregional recurrence and/or } \\
\text { distant metastasis, especially in tumours } \\
\text { with angioinvasion }\end{array}$ \\
\hline
\end{tabular}

\footnotetext{
*Rare exceptions include case reports of parathyroid 'double adenomas' and carcinoma arising from a background of parathyroid hyperplasia.

†Symptoms of hyperparathyroidism include bone pain, renal colic (nephrolithiasis) and neurocognitive symptoms related to hypercalcaemia (weakness, easy fatigability, anxiety, depression, altered cognition).

FHH, familial hypocalciuric hypercalcaemia syndrome; HPT, hyperparathyroidism; HPT-JT, hyperparathyroidism-jaw tumour syndrome; MEN, multiple endocrine neoplasia syndromes; PTH, parathyroid hormone; US, ultrasound.
} 
defined as high serum PTH and normal serum ionised calcium in the absence of known causes of secondary HPT, has been

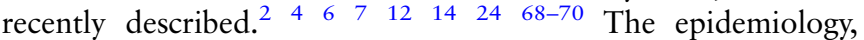
natural history and management of normocalcemic primary HPT remain unclear at this time; however, undoubtedly a subset of individuals will develop hypercalcaemia, while some show target organ alterations such as decreased bone mineral density. ${ }^{1} 24246971$ Secondary HPT presents with high serum PTH and normocalcemia or hypocalcaemia. $7 \begin{array}{lllll} & 10 & 11 & 72 & 73\end{array}$ Although it is initially and adaptive response to a variety of stimuli resulting mainly in extracellular hypocalcaemia (vitamin D deficiency, chronic kidney disease, idiopathic hypercalciuria, calcium malabsorption), long-standing secondary HPT may eventually develop into autonomous HPT (ie, tertiary HPT). ${ }^{710} 1142447274$ Similar to primary HPT, tertiary HPT is biochemically characterised by an elevation of both PTH and calcium in the serum. ${ }^{11}{ }^{74}$ However, tertiary HPT is usually easily distinguished from primary HPT by a readily identifiable aetiology, which in most circumstances is advanced chronic kidney disease. ${ }^{11}$ In light of these findings, careful assessment of medication history (ie, lithium, thiazide), renal function, urinary calcium and family history is important to exclude secondary/ tertiary and hereditary HPT, as their prognosis and management can differ significantly from that of sporadic primary HPT. $^{4} 6711{ }^{42}$ Serum 25-hydroxyvitamin D levels should also be measured; not only is vitamin D deficiency a frequent cause of secondary HPT, it is commonly associated with primary HPT and can mask the patient's hypercalcaemia. ${ }^{4} 6713$

Familial syndromes are reported in about $5 \%$ of patients with primary HPT. 7 13 29-32 42 44 75-81 Clinical findings suggestive of hereditary HPT include early onset of disease ( $<30$ years); family history of hypercalcaemia; skin lesions (lipomas, facial angiofibromas, truncal collagenomas), pituitary adenomas and neuroendocrine tumours (including pheochromocytomas) associated with multiple endocrine neoplasia syndromes; jaw tumour with or without renal cysts (HPT-JT syndrome); hypercalcaemia associated with hypocalciuria or a calcium-to-creatinine clearance ratio $<0.01(F H H){ }^{4} 7$ 30-32 78 82-85 When familial disease is suspected, serum calcium measurement of first-degree relatives should be considered along with other clinical investigations. ${ }^{4} 671330$ In cases where MEN-1 is suspected on the basis of multiglandular primary HPT with or without other concomitant MEN-1 associated tumours, testing for a MEN1 mutation is recommended. ${ }^{86} \mathrm{~A}$ definite diagnosis of FHH may ultimately require demonstration of a germline mutation in CASR, GNA11 and AP2S1. ${ }^{4} 133032427779$ 87-91 A severe neonatal phenotype (neonatal severe HPT) has also been described, presenting with severe HPT and life-threatening hypercalcaemia in the first six months of life. ${ }^{4574244}$

Although rare, parathyroid carcinoma should be considered in all patients with HPT and the following features: severe hypercalcaemia (albumin-corrected calcium $>3 \mathrm{mmol} / \mathrm{L}$ ), extremely high PTH levels ( $>3$ times the upper limit of normal), concomitant bone and kidney involvement, palpable neck mass, jaw tumour, and family history of parathyroid or other endocrine disorders. ${ }^{4} 747495192-101$ Clinically, parathyroid carcinomas tend to present at an earlier age, with equal frequencies in both sexes. $^{42} 47495196102$ Biochemically, a third-generation/secondgeneration PTH ratio $>1$ has been shown to help predict parathyroid malignancy prior to surgery by correlating with other clinical, biochemical and radiological findings. ${ }^{47} 51$ 103-105 Although this method has not been widely accepted, it has been proposed based on the fact that most parathyroid carcinomas overproduce amino-PTH, which is recognised by third-generation but not second-generation PTH assays. ${ }^{47} 51$ 81 103-105 However, rare 'non-functioning' parathyroid carcinomas have also been reported. ${ }^{42}{ }^{47}$ Radiographic lesions suspicious for distant metastasis may also be identified on sestamibi scintigraphy or CT scan, which can be confirmed on biopsy. ${ }^{47424751}$

\section{RADIOLOGICAL INVESTIGATIONS}

In conjunction with clinical and biochemical findings, radiological investigations are necessary to guide treatment decisionmaking in primary HPT (tables 1 and 2). ${ }^{4} 67294297$ 106-108

Extra-parathyroid imaging is performed to assess PTH-related complications on skeletal and renal structures, as positive findings may warrant surgery even in patients with asymptomatic primary HPT. ${ }^{14}{ }^{29}$ For instance, renal ultrasonography is performed to exclude clinically 'silent' nephrocalcinosis and nephrolithiasis, which can occur in up to $20 \%$ of cases. ${ }^{14} 71229$ Measurement of bone mineral density at the lumbar spine, hip and distal third of the forearm should also be investigated using dual-energy X-ray absorptiometry (figure 1A). ${ }^{1471229}$ The distal third of the forearm, enriched in cortical bone, is generally the first site to be affected because PTH preferentially affects cortical bone. ${ }^{4} 671229$ The lumbar spine (richer in trabecular bone) is usually more preserved, whereas the hip region (mixture of cortical/trabecular bone) tends to show intermediate findings. ${ }^{14671229}$ However, it should be noted that a subset of patients $(\sim 15 \%)$ present with a different densitometry profile, with mainly vertebral osteopenia or osteoporosis. ${ }^{6} 1229109$ In patients with severe HPT, plain-film radiography and CT imaging may identify signs of bone disease such as pathological fractures, 'salt and pepper' appearance of the skull, tapering of the distal third of the clavicles, lytic lesions (figure 1B) of the pelvis, long bones and shoulders, and subperiosteal bone erosions in the distal phalanges. ${ }^{146712162965110}$

Parathyroid imaging is used to localise and characterise parathyroid abnormalities preoperatively. ${ }^{4} 6751106-108{ }^{111-113}$ It is particularly helpful in the identification and characterisation of single-gland disease (adenoma or rare carcinoma) although it may also detect multigland parathyroid disease (usually hyperplasia) allowing for the appropriate surgical approach. ${ }^{4} 6751$ 106-108 111112114115 In patients with a predisposition for multigland disease (eg, those with MEN), parathyroid imaging is perhaps most useful in the localisation of recurrent disease as their initial surgery usually entails a four gland parathyroid exploration with resection of most of the parathyroid tissue. ${ }^{116} 117$ Although several imaging modalities have been described, neck ultrasound and ${ }^{99}$ technetium-labelled sestamibi $\left({ }^{99 m} T c\right.$-sestamibi) scintigraphy are currently the most commonly used radiological tools (figure 2). ${ }^{4} 6751$ 106-108 $11111299 \mathrm{mTc}$-sestamibi is taken up by both parathyroid and thyroid tissue, and its uptake is generally increased and prolonged in functioning neoplastic or hyperplastic parathyroid gland(s) (figure 2). ${ }^{4} 6751$ 106-108 111112 In addition, it has the advantage of localising ectopic parathyroid tissue. $^{4} 56751$ 106-108 111112 Recently, dual-tracer subtraction using ${ }^{99 \mathrm{~m}} \mathrm{Tc}$-sestamibi in combination with radioactive iodine $\left({ }^{123} \mathrm{I}\right)$ has also been proposed to separate parathyroid uptake of sestamibi from thyroid uptake to achieve better visualisation of the functioning parathyroid tissue. ${ }^{46751} 106-108$ 111-119

\section{PATHOLOGICAL MANIFESTATIONS OF HYPERPARATHYROIDISM}

In order to better understand the pathological manifestations of HPT (tables 1-3), the characteristics of normal parathyroid glands will also be highlighted here. 
Figure 1 Bone manifestations of primary hyperparathyroidism. (A) Progressive decrease in bone mineral density (BMD) at the lumber spine $(-17.1 \%)$ and hip $(-14.4 \%)$ in a 58-year-old woman with primary hyperparathyroidism. (B) CT showing lytic expansile lesion of the left clavicular head in a 30-year-old man with severe hyperparathyroidism.
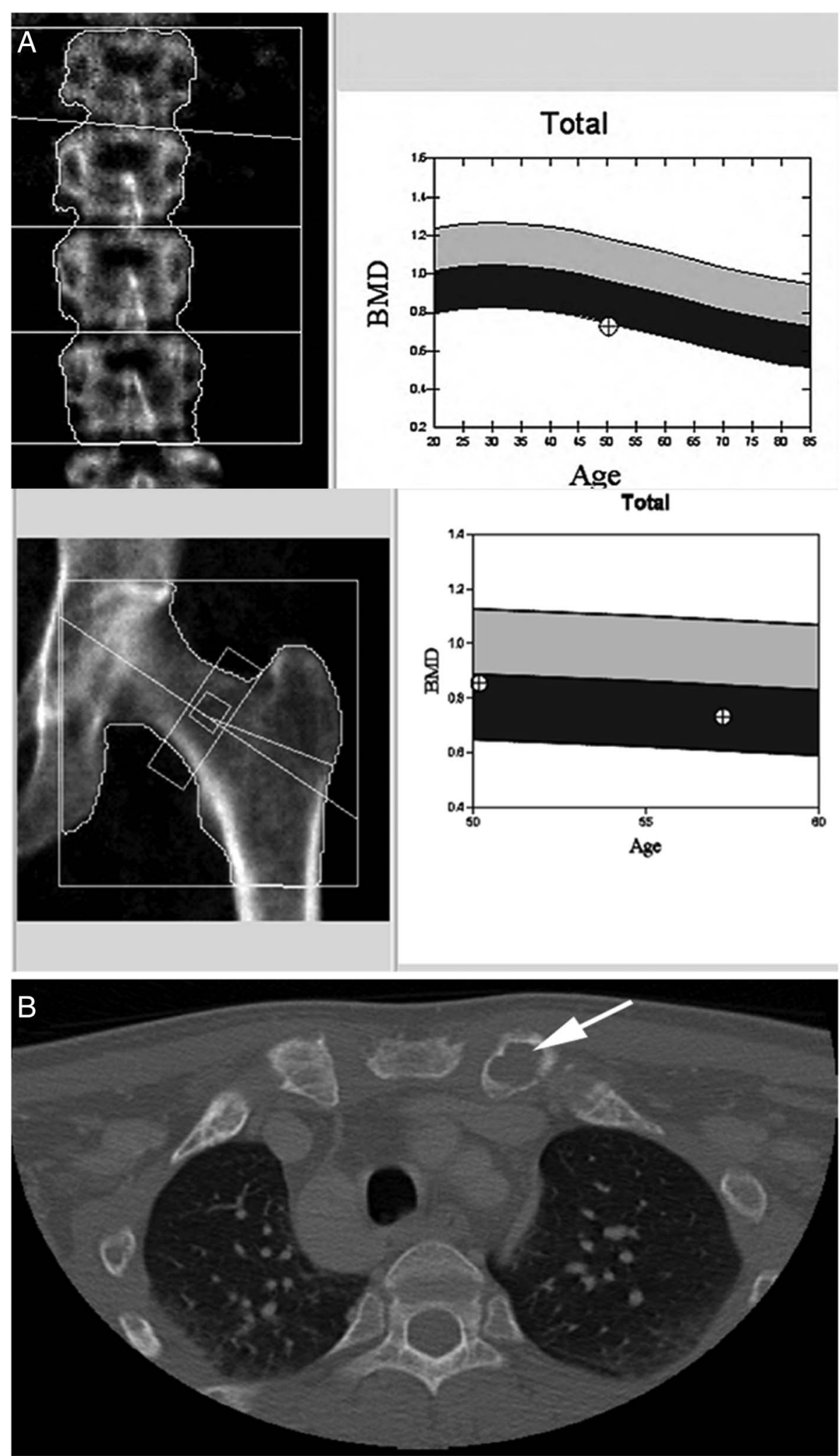

\section{Normal parathyroid}

In healthy individuals, the parathyroid glands are generally 4 in number (two superior, two inferior), although supernumerary parathyroid glands can occur in $2-13 \%$ of the population. $^{38} 42 \quad 44-46120$ It should be noted that all superior glands are located within the thyroid gland or in its pseudocapsule. ${ }^{121}$ Grossly, a normal parathyroid gland appears brown, round-to-ovoid, small (often $<6-8 \mathrm{~mm}$ ) and can weigh up to
40-60 mg each (figure 3). ${ }^{38-40} 4244-4699120$ Occasionally, parathyroid tissue can occur in ectopic locations (near the carotid bifurcation, pericardial sac, mediastinum, retroesophageal space, vagus nerve, angle of the jaw and thyroid gland) as a result of aberrant migration during embryogenesis. ${ }^{38-40} \quad 42 \quad 44-46 \quad 99 \quad 120$ Histologically, each gland is comprised of glandular parenchyma, adipose tissue and an arborising network of blood vessels, generally confined within a thin pseudocapsule. ${ }^{38} 424445$ 

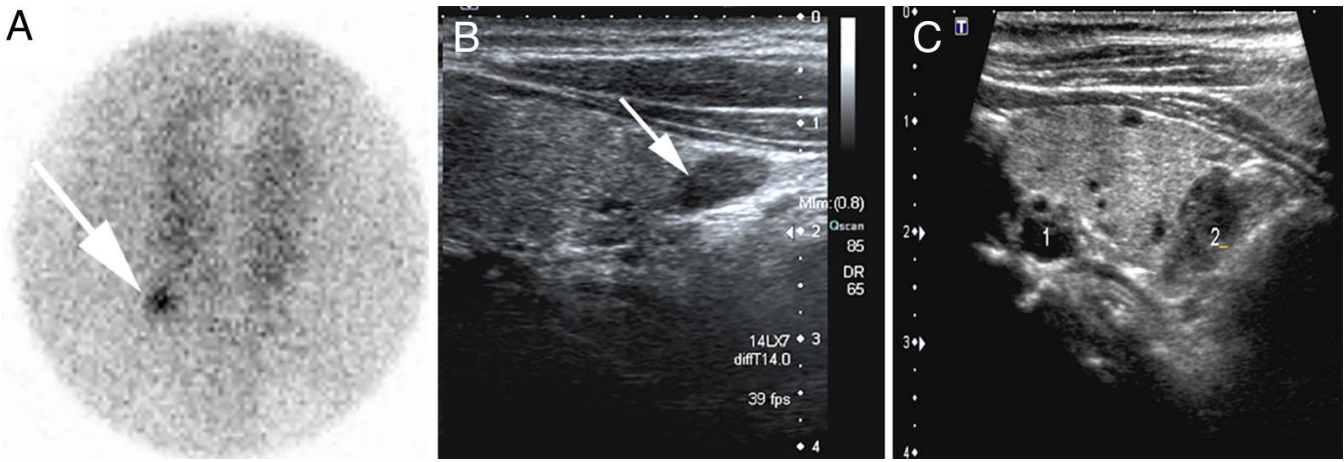

Figure 2 Parathyroid imaging in hyperparathyroidism. Neck ultrasound and ${ }^{99}$ technetium-labelled sestamibi $\left({ }^{99 m} \mathrm{Tc}\right.$-sestamibi) scintigraphy are currently the most commonly used radiological tools. (A) Focal scintigraphic activity in the inferior right pole of the thyroid corresponding to a right lower parathyroid adenoma. (B) Neck ultrasound showing a hypoechoic nodule in the area of focal ${ }^{99} \mathrm{mTC}$-sestamibi persistent activity. (C) Ultrasound image shows two hypoechoic nodules behind the left thyroid lobe corresponding to enlarged parathyroids in a patient with secondary hyperparathyroidism due to end stage chronic renal failure.

The parenchymal cells are composed predominantly of chief cells (main producer of PTH), along with oncocytic cells (rich in mitochondria; also known as oxyphilic cells or oxyphils) and transitional oncocytic cells (representing an intermediate phase between chief cells and oncocytic cells). ${ }^{38-40} 4244-4699120$

\section{Handling of parathyroidectomy specimens and the role of intraoperative consultation}

The clinical history, biochemical work-up, as well as number, size and weight of affected gland(s) are important parameters to consider when rendering a clinicopathological diagnosis of parathyroid proliferations. The initial examination should start with a gross inspection. The parathyroid gland(s) should be carefully weighed and measured after removal of the surrounding fat tissue. ${ }^{39} 414244$ At this stage, it is critical to identify the vascular pole (hilum) before slicing the gland horizontally to this plane. $^{3} 404144$ This step is particularly important, given the fact that an atrophic rim of normal parathyroid tissue, one of the key histopathological features of a parathyroid adenoma, ${ }^{42} 44122123$ is often located at the vascular pole (hilum) of the gland.

Accurate diagnosis of parathyroid proliferations can be difficult or even impossible at the time of the intraoperative assessment. 394042434446123124 The primary role of the intraoperative pathological consultation is to confirm the presence of parathyroid tissue in the resected specimen and to exclude other tissues, such as lymph nodes or thymus, which can be mistaken for parathyroid tissue by the surgeon. ${ }^{35} 39-46123125$ In patients

Table 3 Histopathological and molecular features of primary hyperparathyroidism

\begin{tabular}{|c|c|c|c|}
\hline Diagnosis & $\begin{array}{l}\text { Parathyroid hyperplasia (multigland } \\
\text { disease) }\end{array}$ & $\begin{array}{l}\text { Parathyroid adenoma (single-gland } \\
\text { disease)* }\end{array}$ & Parathyroid carcinoma (single-gland disease)* \\
\hline $\begin{array}{l}\text { Histopathological } \\
\text { features }\end{array}$ & Enlarged cellular glands & $\begin{array}{l}\text { Well-circumscribed tumour with atrophic rim of } \\
\text { normal parathyroid tissue }\end{array}$ & $\begin{array}{l}\text { Large tumour invading adjacent structures, } \\
\text { unequivocal vascular invasion or perineural invasion, } \\
\text { and/or metastasis }\end{array}$ \\
\hline Ancillary biomarkers & $\begin{array}{l}\text { Nodular hyperplasia can express same } \\
\text { biomarkers as adenomas; but may also } \\
\text { express galectin-3 }\end{array}$ & $\begin{array}{l}\text { Preserved expression of parafibromin, Rb, p27, } \\
\mathrm{Bcl}-2 \mathrm{a} \text {, mdm2, APC, and PGP9.5, no p53 } \\
\text { overexpression, negative for galectin-3; Ki67 } \\
\text { index usually }<5 \%\end{array}$ & $\begin{array}{l}\text { Loss of expression of parafibromin, } \mathrm{Rb}, \mathrm{p} 27, \mathrm{Bcl}-2 \mathrm{a} \text {, } \\
\mathrm{mdm} 2, \mathrm{APC} \text {, and overexpression of p53 (rare), } \\
\text { PGP9.5, positivity for galectin-3, increased Ki67 index } \\
(>5 \%)\end{array}$ \\
\hline Inheritance & Hereditary in $>25 \%$ of cases & Usually sporadic & $\begin{array}{l}\text { Usually sporadic ( } 80-90 \%) \text {, with the exception of } \\
\text { HPT-JT as well as isolated familial } \\
\text { hyperparathyroidism associated with germline } \\
\text { HRPT2/CDC73 mutations }\end{array}$ \\
\hline $\begin{array}{l}\text { Molecular } \\
\text { pathogenesis }\end{array}$ & $\begin{array}{l}\text { Abnormal CaSR signalling, cyclin D1 and } \\
\text { Wnt/ß-catenin signalling }\end{array}$ & $\begin{array}{l}\text { Abnormal CaSR signalling, cyclin D1 and Wnt/ } \\
\beta \text {-catenin signalling }\end{array}$ & $\begin{array}{l}\text { Inactivation of parafibromin, abnormal cyclin D1 and } \\
\text { Wnt/ß-catenin signalling }\end{array}$ \\
\hline $\begin{array}{l}\text { Associated somatic } \\
\text { alterations }\end{array}$ & Not defined & $\begin{array}{l}\text { MEN1, CCND1/PRAD1, CDKN1B, CDKIS, CASR, } \\
\text { VDR, ZFX, CTNNB1, EZH2, POT1, APC, SFRPs, } \\
\text { WT1, RIZ1, RASSF1A, HIC1, GSK3 } \beta \text {, microRNA } \\
\text { deregulation }\end{array}$ & $\begin{array}{l}\text { CDC73/HRPT2, APC, PRUNE2, HIC1, GSK3 } \beta, \text { mTOR, } \\
\text { MLL2, THRAP3, PIK3CA, CCND1/PRAD1, CDKN1B, } \\
\text { CDKIs, EZH2, RIZ1, RASSF1, MEN1, WT1, CaSR, } \\
\text { microRNA deregulation, APOBEC mutational } \\
\text { signature }\end{array}$ \\
\hline $\begin{array}{l}\text { Associated germline } \\
\text { alterations }\end{array}$ & $\begin{array}{l}\text { MEN1, RET, CDKN1B, CDC73/HRPT2, } \\
\text { CaSR, GNA11, AP2S1 }\end{array}$ & Not defined & $\begin{array}{l}\text { Inherited inactivated allele of CDC73/HRPT2 in } \\
10-20 \% \text { of cases }\end{array}$ \\
\hline $\begin{array}{l}\text { Associated } \\
\text { hereditary } \\
\text { syndromes }\end{array}$ & $\begin{array}{l}\text { MEN-1, MEN-2A, MEN-4, HPT-JT, FHH-1, } \\
\text { FHH-2, FHH-3, familial hypercalciuric } \\
\text { hypercalcaemia, neonatal severe HPT, } \\
\text { isolated familial HPT }\end{array}$ & Rarely associated with hereditary syndromes & $\begin{array}{l}\text { HPT-JT in } 10-20 \% \text { of cases or isolated familial } \\
\text { hyperparathyroidism }\end{array}$ \\
\hline
\end{tabular}

*Rare exceptions include case reports of parathyroid 'double adenomas' and carcinoma arising in a background of parathyroid hyperplasia.

APC, adenomatous polyposis coli; APOBEC, apolipoprotein B mRNA editing enzyme, catalytic polypeptide-like mutational signature; CaSR, calcium-sensing receptor; CDKIs,

cyclin-dependent inhibitors-encoding genes; FHH, familial hypocalciuria hypercalcaemia syndrome; GSK3 $\beta$, glycogen synthase kinase 3- $\beta$; HPT, hyperparathyroidism; HPT-JT,

hyperparathyroidism-jaw tumour syndrome; MEN, multiple endocrine neoplasia syndrome; PRUNE2, prune homologue 2; Rb, retinoblastoma protein; VDR, vitamin D receptor. 


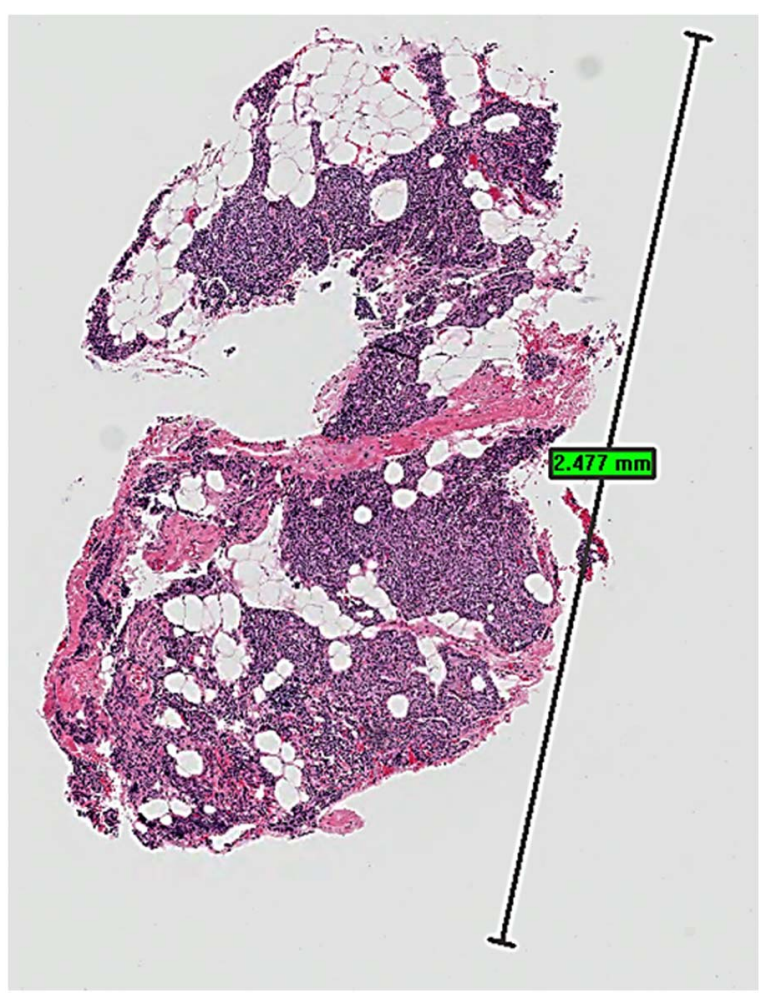

Figure 3 Normal parathyroid gland. A normal parathyroid gland appears grossly brown and round-to-ovoid. It measures less than 6-8 $\mathrm{mm}$ and weighs up to $40-60 \mathrm{mg}$ each.

with HPT, intraoperative confirmation of glandular abnormality (enlarged cellular gland) is also required (figure 4). In the past, pathologists were also asked to assess parenchymal-to-adipose cell ratio and to perform fat stains (oil red O or Sudan IV stains)

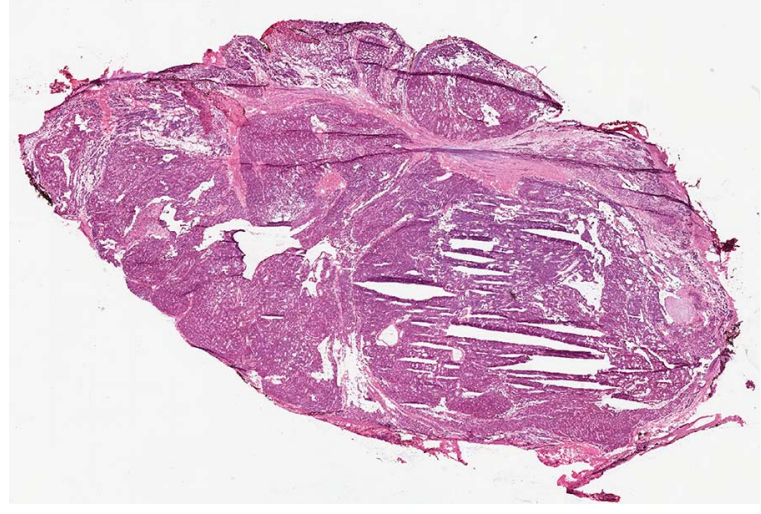

Figure 4 The role of intraoperative consultation in hyperparathyroidism. The primary role of the intraoperative pathological consultation is to confirm the presence of parathyroid tissue and to exclude other tissues mimicking parathyroid gland. The parenchymal-to-adipose cell ratio is not a reliable tool to distinguish an abnormal gland. In patients with hyperparathyroidism, intraoperative confirmation of an abnormal gland based on the weight $(>60 \mathrm{mg})$ and size $(>8 \mathrm{~mm})$ of the gland is also required. Accurate diagnosis of parathyroid proliferations can be difficult or even impossible at the time of the intraoperative consultation. Thus, the term 'enlarged cellular gland' should be applied to abnormal gland at the time of intraoperative consultation. The rapid intraoperative parathyroid hormone assay appears to be a more precise tool to distinguish adenoma from hyperplasia at the time of intraoperative consultation. to diagnose parathyroid proliferations. ${ }^{44} 126$ The value of these stains remains controversial, with most experts agreeing that this approach is not reliable in distinguishing parathyroid adenoma from hyperplasia. While the evaluation of a second parathyroid gland may be an alternative to fat stains, the recent development and adoption of rapid intraoperative PTH assay appears to be a more precise tool to distinguish adenoma from hyperplasia. $^{29} 3642127-129$ In patients with single-gland disease, removal of a solitary gland results in reduction of PTH levels of $>50 \%$, often $>75 \%$, within 10 min. ${ }^{429343642130}$ Consequently, many hospitals with high volumes of parathyroid surgeries use rapid intraoperative PTH measurements, immediately before and 10 min after resection. ${ }^{4} 29343642130$ If a significant drop $(>50 \%)$ in PTH levels is noted, no further exploration is under-

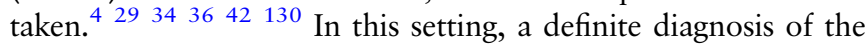
parathyroid pathology is not required at the time of surgery. ${ }^{4} 29343642130$ Immediate hypocalcaemia after surgery is frequently seen in patients with single-gland parathyroid disease and should be monitored accordingly. 429343642130

\section{Histopathological correlates of HPT}

Primary HPT can occur hereditarily ( $5 \%)$ or sporadically $(\sim 95 \%)$ due to parathyroid hyperplasia, adenoma or carcinoma (table 3). ${ }^{38} 39 \quad 41-44 \quad 4699123131$ With the exception of rare double adenomas, parathyroid adenomas and carcinomas are almost always uniglandular (solitary) lesions, whereas hyperplasia represents multiglandular proliferation, which can be asym-

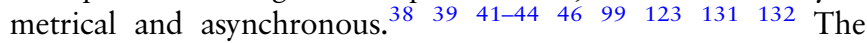
presence of an atrophic rim of hypocellular non-tumorous parathyroid tissue adjacent to a cellular proliferation often allows an accurate diagnosis of 'parathyroid adenoma' in the appropriate clinical and biochemical setting (figure 5). $.^{38} 3941-444699123131$ However, in the absence of an atrophic rim, hyperplasia cannot be excluded at the morphologic level. ${ }^{38} 3941-444699123131$ For this reason, an enlarged parathyroid gland, lacking a normal rim, should be classified as an 'enlarged cellular parathyroid gland'. If biochemical cure is achieved after surgery, a diagnosis of parathyroid adenoma can be rendered, after excluding parathyroid carcinoma. It should be noted that hyperplastic glands can also present small areas of normocellular or slightly cellular tissue indistinguishable from those surround parathyroid

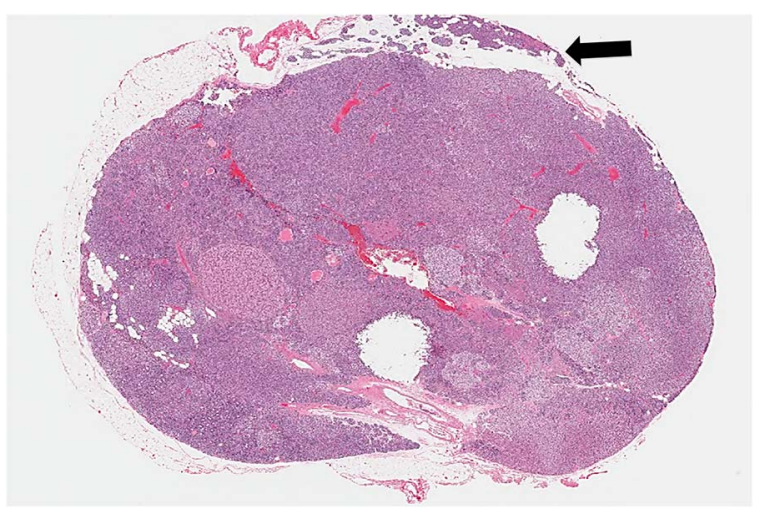

Figure 5 Parathyroid adenoma. With the exception of rare double adenomas, parathyroid adenomas are almost always uniglandular (solitary) lesions. The presence of an atrophic rim of hypocellular non-tumorous parathyroid tissue adjacent to a cellular proliferation often allows an accurate diagnosis of 'parathyroid adenoma' in the appropriate clinical and biochemical setting. 
adenomas. $^{38} 3941-444699123131$ Therefore, correlation with intraoperative PTH levels and postoperative PTH and calcium levels is crucial to render a definitive diagnosis of adenoma. $^{38-4699123131}$

Parathyroid adenomas are by far the most common cause of primary HPT, accounting for $80-85 \%$ of cases. ${ }^{43842} 46$ Foci of cystic change can occur in larger adenomas, particularly in the setting of a familial syndrome (ie, HPT-JT syndrome). ${ }^{43} 44123$ Fibrosis is also seen in some patients with MEN-1 and MEN-4 syndromes, as well as following procedural interventions of the parathyroid gland(s) (eg, fine needle aspiration for PTH measurements and/or cytological examination; ethanol injection) (figure 6). ${ }^{38-40} 42 \quad 44 \quad 4599133$ Microscopically, a parathyroid adenoma is composed of varying proportions of chief, clear, transitional oncocytic and oncocytic cells. ${ }^{38-40} 42444599133$ While 'chief cell' adenomas are the most prevalent type, rare morphological variants have also been reported, including oncocytic cell adenomas, water-clear cell adenomas and lipoadenomas. ${ }^{38-40}$ 42444599133 Rare cases with spindle cell features have also been described. $^{42}$ Various architectural patterns have been reported, including arrangements in cords, nests, sheets, papillary, pseudopapillary and follicles with palisaded appearance around blood vessels (figure 6). ${ }^{38-4042444599133}$ Some parathyroid adenomas show prominent follicular architecture, mimicking thyroid tissue (figure 6). ${ }^{38-404244-4699133}$ However, a distinction can be made based on the observation that the follicles in parathyroid adenomas typically do not contain birefringent calcium oxalate crystals, which are usually seen in thyroid follicles. ${ }^{42} 99134$ Cytologically, the nuclei of tumour cells often appear round and larger than those of adjacent non-neoplastic cells. ${ }^{38-40} \quad 42 \quad 44-46 \quad 99 \quad 133$ Occasionally, the use of immunohistochemistry (positivity for PTH, GATA3 or GCM-2) is helpful to confirm the primary parathyroid origin of an unusual neoplasm (figure 6). ${ }^{94}$ Although scattered mitotic figures can be present, the proliferative index of most adenomas, as assessed by Ki-67 (MIB-1), is generally $<5 \%{ }^{38-404244-469899133135}$

Parathyroid hyperplasia is a multiglandular disorder, causing $10-15 \%$ of cases of primary HPT. ${ }^{4} 38424446$ Three morphological variants can be seen: diffuse (diffuse hyperplasia), localised with one or more nodules (nodular hyperplasia) or a mixture of both patterns (mixed diffuse/nodular hyperplasia) (figure 7). ${ }^{38} 42$ 4445123 The individual hyperplastic glands are grossly increased in size and weight; microscopically, they show chief, oncocytic and/or clear cells. ${ }^{38-4042444599}$ In most cases, chief cells tend to predominate, hence the classic term 'chief cell hyperplasia'. In rare instances, abundant stromal fat is observed, resulting in a morphological variant termed 'lipohyperplasia'. 38-40 42 44 4599 Foci of cystic change with fibrosis and hemosiderin deposition can occur, particularly in long-standing prominent hyperplasia related to chronic renal failure. ${ }^{38-40} 42 \quad 44 \quad 4599$ A rare 'water-clear cell' variant of parathyroid hyperplasia has also been reported, presenting with more florid HPT and hypercalcaemia than the common chief cell hyperplasia, often with grossly, enlarged, cystic and haemorrhagic glands. ${ }^{38-40} 42444599$ Similarly, water-cell adenomas have also been described. ${ }^{38-40} 42 \quad 44 \quad 45 \quad 99 \quad 136-139$ The glycogen-free water-clear cell morphology is attributed to
Figure 6 Various cytological and architectural patterns associated with parathyroid adenomas. Most adenomas consist of chief cells (A), rare morphological variants have also been reported, including oncocytic cell adenomas, mixed cellular adenomas (B), water-clear cell adenomas (C), and lipoadenoma. Various architectural patterns have been reported, including arrangements in cords, nests, sheets, papillary/pseudopapillary (D) and follicles (E). Some parathyroid adenomas show prominent follicular architecture and proteinaceous material in the lumina, mimicking thyroid tissue (E). However, parathyroid proliferations with follicular growth typically lack birefringent calcium oxalate crystals, which are often seen in thyroid follicles. Occasionally, the use of immunohistochemistry (positivity for parathyroid hormone (PTH), GATA3 or GCM-2) is helpful to confirm the primary parathyroid origin in challenging cases (F; PTH immunostain).

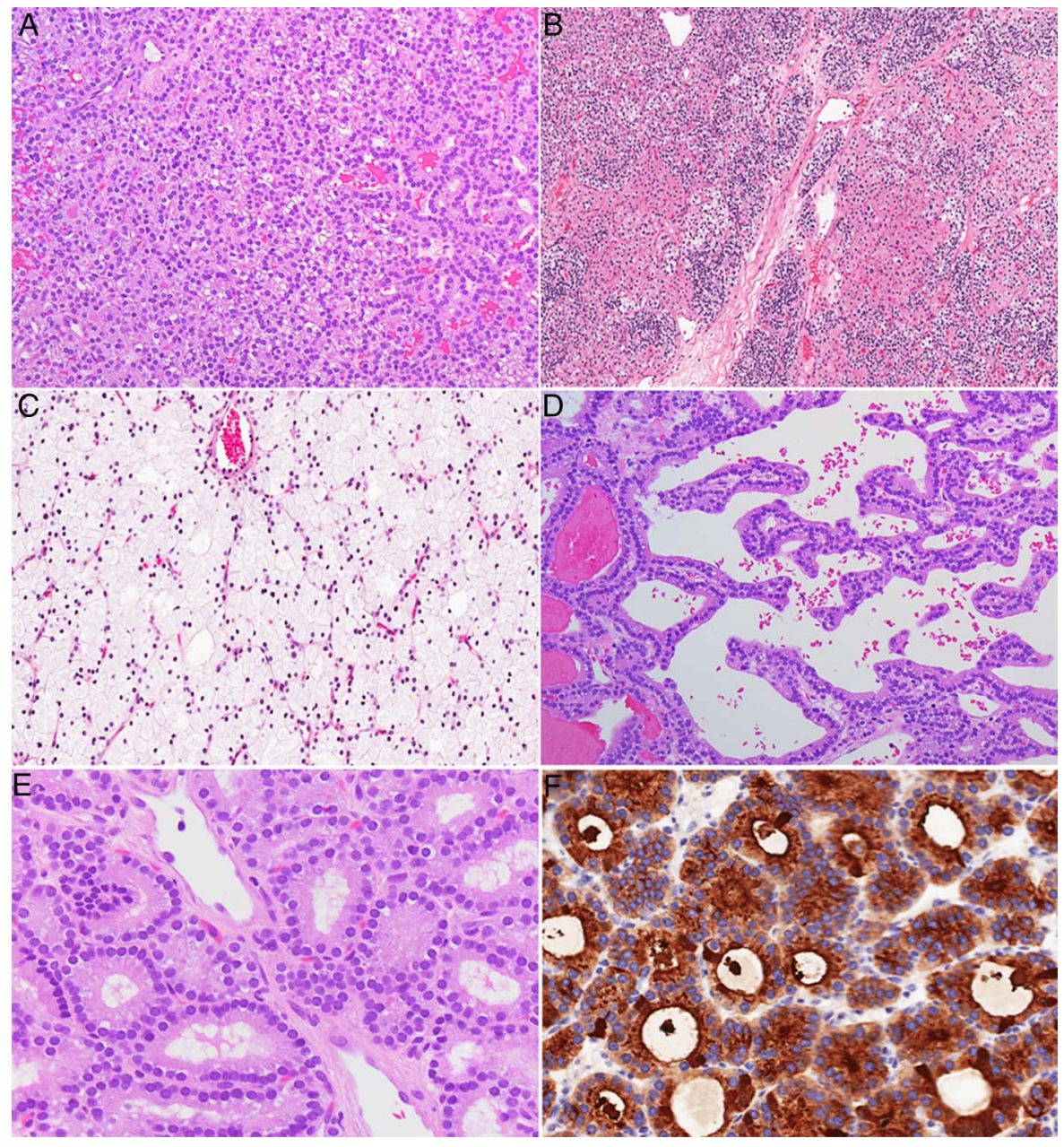


Figure 7 Parathyroid hyperplasia. Unlike parathyroid adenoma and carcinoma, parathyroid hyperplasia is a multiglandular parathyroid disease. In this photomicrograph, parathyroid hyperplasia is illustrated in a three and half parathyroidectomy specimen.
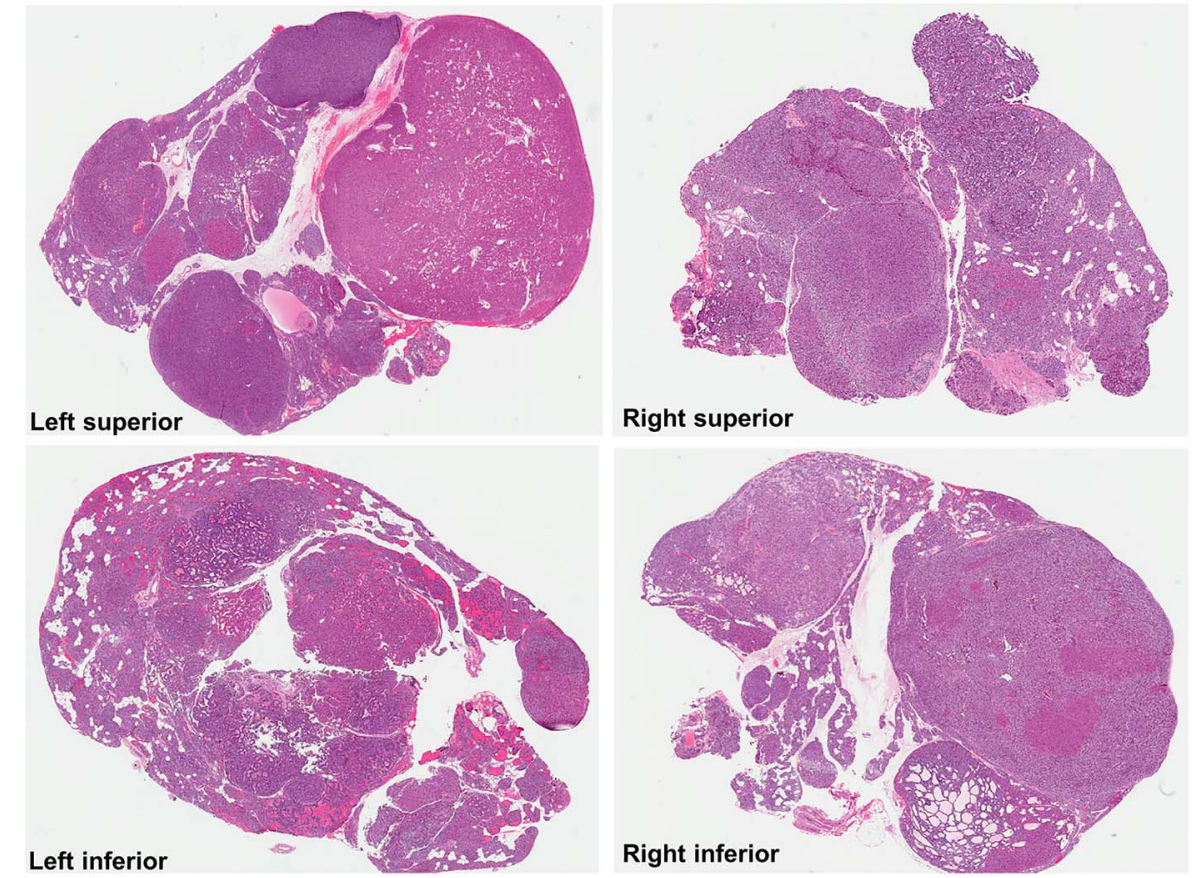

cytoplasmic clearing due to the presence of numerous small vacuoles derived from the Golgi apparatus. ${ }^{38-40} 42444599$ 136-139 The molecular basis underlying this 'water-clear cell' variant morphology remains unclear at this time. ${ }^{38-40} 42444599$ 136-139

Rare cases of 'double adenomas' have also been described to cause multigland disease in primary HPT. ${ }^{42} \quad \begin{array}{llllll}44 & 123 & 132 & 140\end{array}$ Since the morphological distinction between adenomas and asymmetrical nodular hyperplasia is somewhat arbitrary at times, there is controversy as to whether double adenomas are truly a distinct clinical and biological entity from nodular hyperplasia. ${ }^{39} 40424446123132140$ Furthermore, emerging molecular data suggest that the nodules in parathyroid nodular hyperplasia represent clonal proliferations that are more closely related to adenomas, making the distinction between multiple adenomas and nodular hyperplasia even more ambiguous. ${ }^{5} 112931333942$ $4446748099141-145$ In fact, this is best demonstrated in patients with MEN syndromes (MEN-1, MEN-4), as well as those with tertiary HPT, who present with multiglandular adenomas; these tumours represent distinct clonal proliferations on molecular studies but are clinically thought to be hyperplasia due to multiglandular involvement. ${ }^{5} 112931 \quad 33 \quad 3942 \quad 44 \quad 46 \quad 74 \quad 8099 \quad 141-146$ In light of these findings, the term 'nodular parathyroid disease', rather than nodular hyperplasia, may seem more appropriate to reflect the molecular basis of these clonal proliferations arising in a background of polyclonal diffuse hyperplasia. 5112931333942 4446748099 141-146 In other terms, this terminology may seem more accurate when designating neoplastic proliferations involving multiple parathyroid glands.

Secondary HPT is generally caused by diffuse parathyroid hyperplasia in response to prolonged reduced levels of extracellular calcium from various secondary aetiologies. ${ }^{7} 114244$ In late stages, the emergence of an autonomous PTH-producing neoplasm (usually adenomas or rare carcinoma) from a background of secondary hyperplasia has been described, causing 'tertiary byperparathyroidism'. Clinically, this histopathological progression from diffuse to nodular parathyroid hyperplasia is associated with the development of refractory HPT and new hypercalcaemia, in patients with previously controlled secondary HPT. ${ }^{7} 11 \quad 42 \quad 44 \quad 7499 \quad 143$ 147148 At the molecular level, this progression sequence has been linked to clonal transformation from diffuse polyclonal hyperplasia due to decreased calcium-sensing receptor (CaSR)

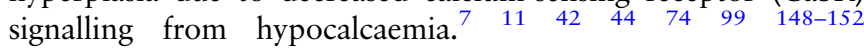
Morphologically, parathyroid hyperplasia with prominent nodular configuration may show areas of haemorrhage, cyst formation, fibrosis and chronic inflammation, which often correlate with the degree of HPT. ${ }^{71} 4244$ Cytologically, chief cells tend to predominate in early phases of secondary HPT, with gradual replacement by oncocytic cells described in late stages of the disease. 7114244

While most parathyroid tumours are benign neoplasms (adenomas), parathyroid carcinomas can occur in $<1-5 \%$ of patients with HPT. ${ }^{4} 73940 \quad 42-44 \quad 4651 \quad 97-99 \quad 102123153$ Grossly, these tend to be larger (mean diameter of $3.4 \mathrm{~cm}$ and weight of $19.15 \mathrm{~g}$ ) and can be densely adherent to thyroid or surrounding soft tissues intraoperatively. ${ }^{39} 40424344465196-98123$ The diagnosis of malignancy is rendered when a parathyroid neoplasm exhibits any of the followings: vascular invasion (tumour cells invading the vessel wall and intravascular tumour cells admixed with thrombus), perineural invasion, invasive growth into adjacent structures/organs and/or metastasis (lymph nodes or distant organs; often lung, liver, bone) (figure 8). ${ }^{39} \quad 40 \quad 42-44 \quad 46 \quad 51 \quad 96-$ 98123153 Nonetheless, it should be noted that the diagnosis of malignancy should not be based alone on the identification of the following morphological features: as broad fibrous bands, increased mitoses, nuclear atypia, necrosis and pleomorphism. These findings may also be present in some benign parathyroid

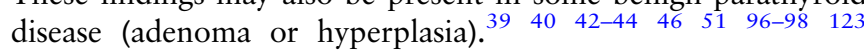
Architecturally, parathyroid carcinomas tend to show solid growth pattern with tumour cells arranged in cohesive cellular masses, although nesting or trabecular growth patterns can also occur. $^{42-44} 46123$ Their cytological composition is similar to parathyroid adenomas, with varying proportions of chief cells, oncocytes, transitional oncocytes and scattered water-clear cells. $^{42-44}{ }^{46}{ }^{123}$ Most parathyroid carcinomas show mild-to-moderate nuclear atypia, which is indistinguishable from 
Figure 8 Parathyroid carcinoma. Common morphological findings encountered in parathyroid carcinomas include the presence of broad fibrous bands $(A)$, necrosis and solid/sheet-like growth pattern (B). In some cases, increased mitotic activity, atypical mitoses and nuclear atypia may be identified. The identification of any of these features is not diagnostic of parathyroid carcinoma. The diagnosis of malignancy is typically rendered when a parathyroid tumour shows any of the followings: (1) vascular invasion (C), (2) perineural invasion, (3) invasive growth into adjacent structures (D; computerised tomography showing a parathyroid carcinoma invading trachea) and (4) metastasis. In addition, the use of ancillary biomarkers is extremely valuable to support or exclude a diagnosis of malignancy. In particular, nuclear and/ or nuclear loss of parafibromin expression is considered a diagnostic feature of parathyroid carcinoma. Please note that the vascular endothelial cells and few scattered mesenchymal cells are positive for parafibromin; however, there is global loss of nuclear parafibromin expression in a parathyroid carcinoma (E).
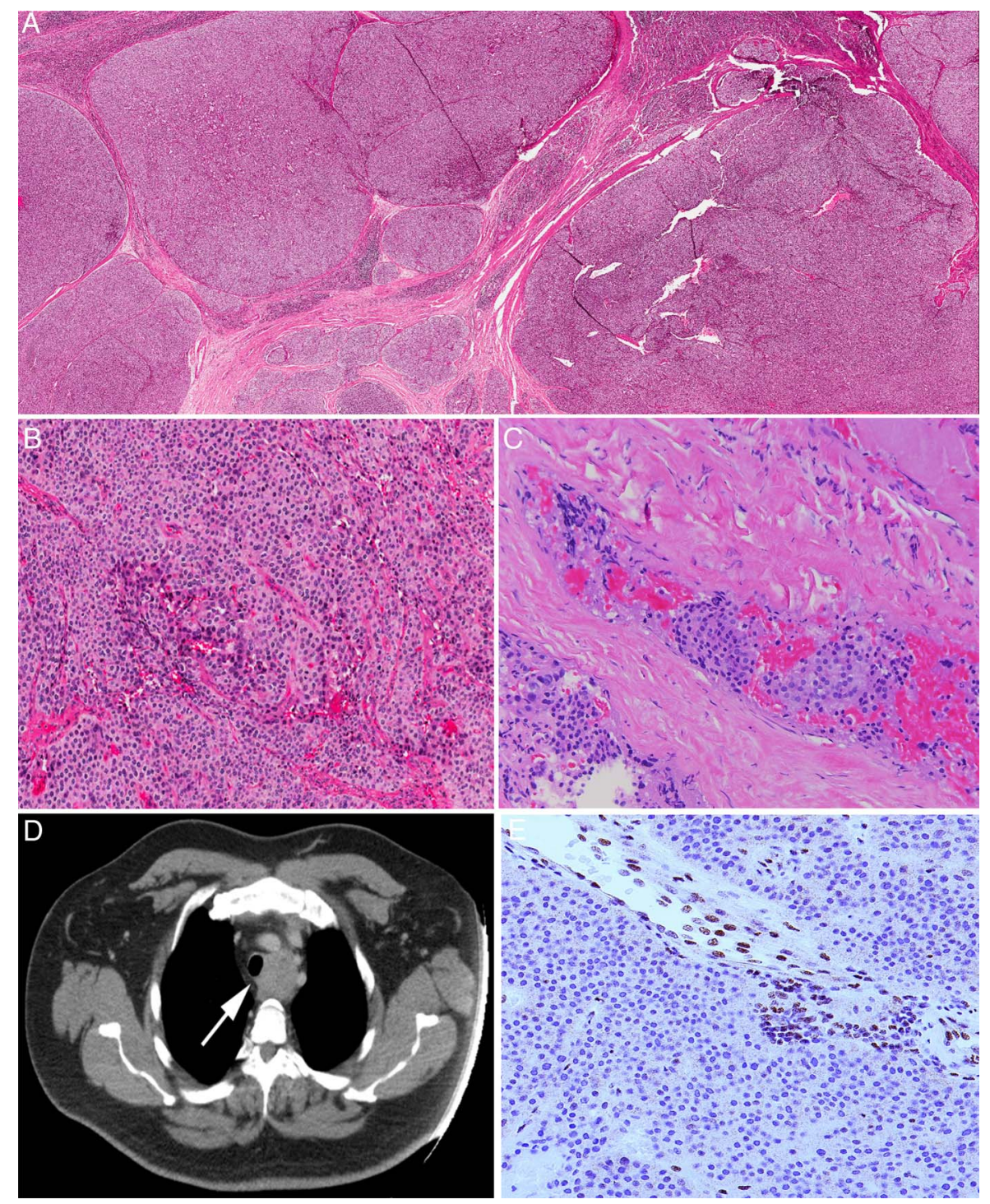

adenomas. $^{39} 40 \quad 42-44 \quad 46519798 \quad 123$ Overall, the distinction between parathyroid carcinomas and adenomas is extremely difficult on cytology, with the exception of a subset of carcinomas that exhibit significant nuclear pleomorphism with macronucleoli. $^{39} 4042-4446519798123$ A triad of high-risk histopathological features (necrosis, macronucleoli, $>5$ mitoses per 50 high-power fields) has been reported to predict malignant behaviour in some parathyroid tumours. ${ }^{42} 120154$

'Atypical adenomas' remain a controversial pathological entity in medicine. In the parathyroid glands, these represent borderline neoplasms showing some histopathological findings of parathyroid carcinomas (band forming fibrosis, increased mitotic activity, presence of tumour cell within a thickened capsule) but lacking the definite diagnostic features of malignancy (invasion into adjacent tissues, vascular invasion and/or metastases). ${ }^{38} \quad 40 \quad 42-44$ $4698123153-156$ The practising pathologist should be aware of the fact that fibrosis can occur in many situations including previous manipulations (post-FNA biopsy for PTH measurements or cytological examination, or ethanol injection), MEN1/MEN4 syndrome, lithium intake or long-standing chronic renal failure related-parathyroid hyperplasia, in the setting of parathyroiditis or in large degenerated adenomas. ${ }^{153}$ While the parathyroids do not have a true anatomic capsule, fibrotic bands at the periphery of the gland can mimic tumour cells within a thickened capsule.
As discussed earlier, mitotic figures can be present in some benign parathyroid disease. ${ }^{153}$ In reality, the concept of 'atypical parathyroid adenoma' probably stems from the previous limits of the histopathological examination, whereby borderline parathyroid tumours with 'equivocal' histological features could not be classified with certainty based on morphology alone, given significant inter-observer variability as well as the lack of clinicopathological correlations in many practices. ${ }^{38} 40 \quad 42-4698 \quad 123 \quad 153$ 155-158 However, with recent developments in molecular pathology and ancillary tools, the classification of these borderline tumours has been greatly refined. ${ }^{153}$ When used in the appropriate clinical and pathological setting, ancillary biomarkers serve a crucial role in the distinction of malignancy in these borderline tumours, thereby enhancing the accuracy of the pathological examination. $38424345469899155156158-161$

In diagnostically challenging cases, the use of ancillary biomarkers is extremely valuable to support or exclude a diagnosis of malignancy, while uncovering differences in molecular phenotypes and prognosis. ${ }^{38-40} 4243469899$ Based on the currently available evidence and our own experiences, loss-of-expression of retinoblastoma protein ( $R b), B c l-2 a, p 27$, parafibromin, $m d m 2$ and APC, as well as increased MIB-1 (Ki67) proliferative index $>5 \%$, overexpression of $p 53$ and positivity for galectin-3 (in the absence of multiglandular disease) favours a diagnosis of 
malignancy in a parathyroid neoplasm with worrisome histopathological features. $^{31} 333842-4649879899141153155156158-$ 164 In particular, the use of parafibromin immunostain (figure $8 \mathrm{E}$ ) is very helpful to differentiate between parathyroid adenomas (intact nuclear and nucleolar parafibromin expression) and parathyroid carcinomas (complete loss of nuclear or nucleolar

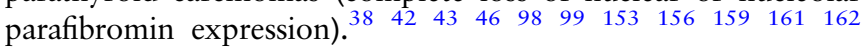
Recently, routine assessment of parafibromin staining has been proposed in all parathyroid carcinomas to help select patients for genetic testing and to predict prognosis: those with parafibrominnegative parathyroid carcinomas had a significantly higher risk of recurrence, a decreased 5 -year survival of 59\% and a decreased 10 -year survival of 23\%, which may warrant closer surveillance. ${ }^{47} 158162$

Parathyromatosis is a rare cause of persistent or recurrent HPT after parathyroidectomy. ${ }^{39} \quad 42 \quad 44 \quad 157 \quad 165$ Some authors believe that this entity represents implantation of benign parathyroid tissue that spilled during surgery, whereas others believe that it reflects local recurrence and/or parathyroid malignancy. ${ }^{39} 4244157165$ Clinical information, presence or absence of invasive growth (especially angioinvasion) and ancillary tools may be helpful in making this distinction. 394244157165

\section{PATHOGENESIS AND MOLECULAR GENETICS OF HPT Normal physiology of PTH secretion}

In normal physiology, PTH secretion is mediated by the CaSR signalling pathway. ${ }^{73} 80881411^{166-169}$ CaSR, encoded by CaSR gene, is a G-protein-coupled receptor found on the surface of parathyroid chief cells. In the presence of circulating calcium, CaSR is activated and recruits phospholipase $C \beta$, through $G_{q}$ and $G_{11}{ }^{7} 338088141 \quad 166-169$ This leads to a complex series of reactions involving production of inositol triphosphate, release of calcium from intracellular stores, elevation of diacylglycerol concentrations, activation of protein kinase C, phosphorylation and internalisation of CaSR. ${ }^{7} 3380141168169$ Ultimately, activation of CaSR signalling pathway suppresses PTH secretion by two mechanisms: first, CaSR signalling activates Goq and phospholipase A2, generating arachidonic acid metabolites, which have been shown to inhibit PTH secretion directly; second, vitamin D receptor (VDR) is overexpressed on parathyroid chief cells, thereby increasing their sensitivity to the negative feedback exerted by $1,25(\mathrm{OH})_{2}$-vitamin $\mathrm{D}$, further suppressing PTH production. 73380141168169 When hypocalcaemia occurs, CaSR signalling is downregulated, and this allows the parathyroid chief cells to release the PTH stored in their cytoplasmic granules, while concurrently increasing $P T H$ gene transcription and protein synthesis. 73380141168169 PTH binds to PTH/PTH-related peptide receptors at various sites in the body, stimulating osteoclast-mediated bone resorption, renal reabsorption of calcium and $1,25(\mathrm{OH})_{2} \mathrm{D}$ synthesis to increase calcium levels. ${ }^{7} 33 \quad 80141 \quad 168 \quad 169$ With the rise of circulating calcium levels, a classic endocrine feedback loop occurs, whereby the CaSRs and its signalling pathway are reactivated, silencing PTH secretion. $73380141 \quad 168 \quad 169$ In HPT, various alterations inactivating CaSR signalling pathway can occur,

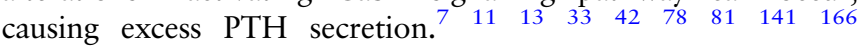
Furthermore, if downregulation of CaSR persists over time, studies have shown that it can lead to aberrant cell growth and proliferation (thought to be related to aberrant $\mathrm{Wnt} / \beta$-catenin and cyclin D1 signalling), suggesting that CaSR signalling may serve a tumour suppressor function in the parathyroid glands. 71133427881141152166 170-172

\section{Hereditary HPT}

Most patients with inherited parathyroid disease present with multiglandular involvement (ie, parathyroid hyperplasia), although rare solitary proliferations can also occur. ${ }^{30} \quad 38 \quad 4244$ 4699143 Common hereditary syndromes associated with HPT include familial cancer predisposition syndromes (MEN-1, MEN-2A, MEN-4 and HPT-JT syndromes) and hereditary 'hypercalcemic' syndromes related to aberrant CaSR signalling (FHH-1, FHH-2, FHH-3, neonatal severe HPT and familial hypercalciuric hypercalcaemia). ${ }^{13} 293032384244468399141143$ Rarely, inherited HPT can occur in a non-syndromic fashion, also known as 'familial isolated hyperparathyroidism', due to germline mutations of MEN1, CDC73/HRPT2, CaSR or cyclindependent kinase inhibitor (CDKI)-encoding genes (CDKN1B, CDKN1A, CDKN2B and CDKN2C). ${ }^{1329304299141173}$

MEN syndromes represent a group of autosomal-dominant cancer predisposition syndromes. ${ }^{4} 73242 \quad 141 \quad 143174$ Three distinct types (MEN-1, MEN-2A, MEN-4) are associated with HPT. $^{32} 42141{ }^{143}$ MEN-1 syndrome is caused by germline inactivating mutations in the tumour suppressor gene MEN1 (11q13), encoding 'menin' protein, which is thought to prevent nuclear translocation of $\beta$-catenin, thereby suppressing Wnt/ $\beta$-catenin signalling, a well-known tumorigenesis pathway. ${ }^{32} 42$ 141143175 Phenotypically, MEN-1 is characterised by the development of multiglandular parathyroid adenomas (90\%), gastroenteropancreatic neuroendocrine tumours (60\%) and pituitary adenomas (30\%); additional tumours reported in this syndrome include adrenocortical tumours, facial angiofibromas, collagenomas, lipomas and/or other neuroendocrine tumours of various sites (thymus, lung, stomach). ${ }^{32} 428599141143176$ The mechanisms underlying tumorigenesis in this syndrome appear to be related to somatic inactivation of the wild-type allele, in addition to an inherited altered copy of the MEN1 gene. $^{32} 428599141143176$

Recently, a subset of patients presenting with multiglandular parathyroid disease and what appeared to be MEN-1 phenotype but lacking $M E N 1$ gene mutation were subsequently given the diagnosis of MEN-4 syndrome (also known as 'MEN X syndrome'). ${ }^{42} 859899141143176$ These patients harboured inactivating germline mutations in the tumour suppressor gene CDKN1B (12p13.1; encoding the CDKI, p2 $7^{\mathrm{kip} 1}$, implicated in cyclin D1 signalling). ${ }^{42} \quad 85 \quad 98 \quad 99 \quad 141 \quad 143 \quad 176$ Phenotypically, patients with MEN-4 are almost indistinguishable from those with MEN-1 related disease. 44246859899141143176 On pathological examination, both MEN-1 and MEN-4-related parathyroid proliferations may show regions of fibrosis and nodularity. ${ }^{39} 4244468599176$

MEN-2A syndrome is characterised by activating germline mutations in the RET proto-oncogene (10q11.2), predisposing to the development of HPT (20-30\%), medullary thyroid carcinoma arising from a background of precursor C-cell hyperplasia (also known primary or neoplastic C-cell hyperplasia) and pheochromocytomas arising in adrenal medullary hyperplasia. ${ }^{4} 32424499141143177178$

HPT-JT is another autosomal-dominant cancer predisposition syndrome associated with HPT due to germline inactivating mutations of CDC73 (formerly known as HRPT2; 1q31.2). ${ }^{4}$ 324251141158161179 CDC73/HRPT2 encodes the parafibromin protein, which serves a key tumour suppressor role in the parathyroid glands, by interacting with polymerase associated factor 1 (PAF1) in histone ubiquitination/methylation, mediating gene transcription, inducing apoptosis, inhibiting cyclin D1 signalling, regulating $\mathrm{Wnt} / \beta$-catenin signalling and growth factor gene

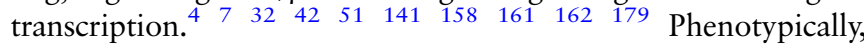


HPT-JT syndrome is characterised by primary HPT, as well as fibro-osseous lesions in the mandible and maxilla, and occasional uterine and renal lesions, including cysts, hamartomas, renal cell carcinoma and Wilms tumours. ${ }^{4} 732141158161$ The HPT is usually attributed to multiglandular parathyroid disease, comprising of multiple parathyroid nodules/adenomas associated with cystic change; about $10-20 \%$ of these lesions eventually progress to parathyroid carcinomas, often due to bi-allelic inactivation of CDC73/HRPT2 and complete loss of parafibromin expression. 4314251141158

In addition to the previously described cancer predisposition syndromes, a group of familial 'hypercalcemic' syndromes (FHH-1, FHH-2, FHH-3, neonatal severe HPT, familial hypercalciuric hypercalcaemia) has been reported to cause HPT, due to aberrant inactivation of CaSR signalling in the parathyroid glands, kidneys and skeletal bones. ${ }^{13} 3242757677141$ These conditions are generally inherited in an autosomal-dominant manner and appear to have near-complete penetrance for the phenotypical expression of hypercalcaemia. ${ }^{13} 32 \quad 42 \quad 75-77141167$ Among these, FHH type 1 is the most classic form, characterised by germline heterozygous inactivating mutations of CaSR (3q21.1), encoding CaSRs. ${ }^{13} 32 \quad 4275-77141 \quad 167$ Clinically, affected patients are typically asymptomatic and present with inappropriate hypocalciuria in the setting of overt hypercalcae-

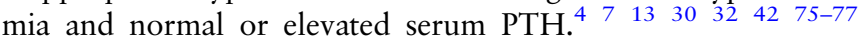
141167 At the molecular level, this phenomenon is mainly attributed to mutant CaSR in the kidney, preventing the normal physiological hypercalciuric response to hypercalcaemia. ${ }^{4} 7$ $1330324275-77{ }^{141}$ Although concurrent primary HPT due to a parathyroid adenoma can occur, the majority of patients with FHH-1 do not have detectable parathyroid disease, and therefore rarely benefit from parathyroidectomy. ${ }^{73} 29303442141180181$ Pathologically, parathyroid enlargement (hyperplasia) has been reported in $15-20 \%$ of cases. $^{3} 32424483182183$

In addition to FHH-1, a severe neonatal phenotype (neonatal severe primary HPT) has been described to cause multiglandular parathyroid disease due to germline homozygous inactivating mutations of the CaSR gene. ${ }^{4} 7132942141$ Clinically, patients with this condition typically present shortly after birth, with life-threatening hypercalcaemia, hypocalciuria and severe $\mathrm{HPT}^{4}{ }^{7} 13293042{ }^{141}$ In contrast to FHH-1, neonatal severe HPT generally requires urgent total parathyroidectomy to prevent a fatal outcome in affected patients. ${ }^{5} 343436$ On pathological evaluation, the parathyroid glands are visibly enlarged, hyperplastic and hypercellular. ${ }^{4713} 3032424446$

A milder form, known as familial hypercalciuric hypercalcaemia (or autosomal-dominant moderate HPT), has also been reported to cause HPT due to germline inactivating mutation in the intracytoplasmic tail domain of the CaSR gene. ${ }^{13} \quad 3042$ 141184 Clinically, affected patients present with elevated calcium and PTH levels, an appropriate hypercalciuric response, hyper-

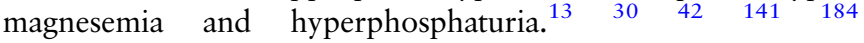
Normalisation of calcium levels has been described in some

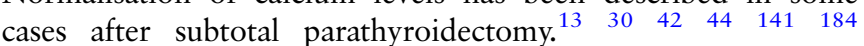
Pathologically, multiglandular parathyroid disease (ie, nodular hyperplasia) is observed in most cases. ${ }^{13} 304244141184$

Recently, two novel forms of FHH (types 2 and 3) have been uncovered. ${ }^{13} 32889091141185$ FHH-2 and FHH-3 are associated, respectively, with germline inactivating mutations of GNA11 (19p13.3) and AP2S1 (19q13.2) genes. ${ }^{13} 32889091141185$ GNA11 gene encodes the $\alpha$-subunit of $\mathrm{G}_{11}$, one of the principal $\mathrm{G}$ proteins activating CaSR signalling pathway, whereas $A P 2 S 1$ gene encodes the adaptor protein $2 \sigma$-subunit involved in CaSR endocytosis. $^{13} 32889091141185$ Both mutations in GNA11 and AP2S1 genes cause hypocalciuric hypercalcaemia though aberrant inactivation of CaSR signalling, similar to FHH-1. ${ }^{13} 32889091141185$ Phenotypically and pathologically, patients with $\mathrm{FHH}-2$ typically present with features indistinguishable from $\mathrm{FHH}-1$, whereas those with FHH-3 tend to present with osteomalacia, higher levels of PTH and more frequent parathyroid gland involvement (hyperplasia). ${ }^{313} 3242889091141185$

\section{Sporadic parathyroid adenomas}

Most parathyroid adenomas are sporadic neoplasms. ${ }^{39} 42-44141$ Although the majority of cases do not have an identifiable risk factor, epidemiological studies suggest that a previous history of ionising radiation predisposes to the formation of sporadic parathyroid tumours. ${ }^{4} 7842$ Somatic alterations in MEN1 and CCND1/PRAD1 genes have emerged as important drivers in the development of $25-40 \%$ of sporadic parathyroid adenomas. ${ }^{42} 4681141186187$

As discussed previously, MEN1 and its gene product, menin, are thought to serve a tumour suppressor role by regulating Wnt/ $\beta$-catenin signalling, a well-documented pathway in tumorigenesis. ${ }^{141} 175188$ Although an inherited mutant copy of the MEN1 gene may be sufficient to cause multiglandular parathyroid disease (hyperplasia) and HPT (in MEN-1 syndrome or isolated familial HPT), an additional somatic inactivating mutation in the remaining copy of MEN1 (ie, the wild-type allele) is generally required for the development of sporadic parathyroid tumours $\left(>25 \%\right.$ in some series). ${ }^{42} 81{ }^{141}$ Alternatively, pure somatic mutations can result in bi-allelic inactivation of MEN1, seen in some parathyroid adenomas. ${ }^{141} 189190$ These findings are consistent with comparative genomic hybridisation reports, where loss of $11 \mathrm{q}$ (locus of MEN1) is the most frequent alteration in adenomas; losses of $1 \mathrm{p}, 6 \mathrm{q}, 9 \mathrm{p}, 11 \mathrm{p}, 13 \mathrm{q}$ and $15 \mathrm{q}$ (possible loci for undiscovered tumour suppressor genes) and gains in $7,16 \mathrm{p}$ and $19 \mathrm{p}$ (possible loci for undiscovered protooncogenes) have also been reported. ${ }^{42} 141191$

CCND1/PRAD1 (11q13) is a proto-oncogene, encoding cyclin D1 protein, a holoenzyme thought to inactivate the tumour-suppressor retinoblastoma protein $(\mathrm{Rb})$, inducing cellular proliferation. ${ }^{31} 3380811411^{192-196}$ Somatic activating alterations of CCND1/PRAD1 gene, causing excess cyclin D1 signalling, have been reported in $20-40 \%$ of sporadic parathyroid adenomas. $^{31} 338081141$ 192-196 Deregulation of CCND1/ PRAD1 gene expression can occur as a result of rearrangements with PTH promoter gene $(\sim 8 \%)$ and/or other enhancers/promoters, leading to amplification or transcriptional activation of cyclin D1. 313338468081141 192-196

Concurrent to the discovery of germline mutations in CDKI-encoding genes causing familial HPT (in MEN-4 syndrome and isolated familial HPT), somatic alterations of CDKI-encoding genes (CDKN1B, CDKN1A, CDKN2B, $C D K N 2 C)$ were also identified in sporadic parathyroid adenomas. $^{31} 3338468081141173197$ Of these, somatic inactivating mutations of the CDKN1B gene (encoding $p 27^{k i p 1}$ ) causing excess cyclin D1 signalling have been well described, and this finding was further corroborated by studies showing decreased expression of p27 in sporadic parathyroid adenomas at both the RNA and protein levels, supporting its role in parathyroid tumorigenesis. ${ }^{42} 141$ 197-199

Despite its well-documented role in hereditary HPT, somatic mutations of the CaSR gene have not been identified in sporadic disease. $^{13} 4276141152200$ Nonetheless, several studies reported that a significant subset of sporadic parathyroid adenomas display aberrant CaSR signalling, characterised by reduced expression of VDRs and CaSRs. ${ }^{13} 4276141150152172$ 200-204 
The exact mechanism underlying loss of expression of VDR and CaSR remains unclear, although genetic and epigenetic alterations in their respective genes have been sought but not found. $^{13} 42 \quad 76 \quad 141 \quad 150-152 \quad 172 \quad 200-204$ Given the fact that the pathogenesis of $>50 \%$ of sporadic parathyroid adenomas remains unknown, these findings certainly raise the possibility that undiscovered somatic alterations, causing deregulation of CaSR signalling (either upstream or downstream of CaSR and VDR), may play an important role in parathyroid

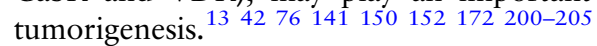

The recent use of whole-exome sequencing in parathyroid adenomas revealed additional somatic mutations, involving $Z F X$ ( $\sim 5 \%$; a putative proto-oncogene thought to be a downstream target of cyclin D1); CTNNB1 (2-5\%; encoding $\beta$-catenin), EZH2 ( $1 \%$; a putative oncogene involved in histone methyltransferase activity and thought to cause aberrant accumulation of $\beta$-catenin) and POT1 ( $<1 \%$; regulator of telomere integrity and genome stability). ${ }^{82} 141186187206-209$

Over the past few years, DNA methylation and microRNA profiling studies have uncovered important epigenetic alterations in sporadic parathyroid tumours. ${ }^{141} 152205$ 210-212 When compared to normal parathyroid tissue, parathyroid neoplasms were shown to have aberrant hypermethylation of tumour suppressor genes in Wnt/ $\beta$-catenin signalling (APC, SFRP1, SFRP2, SFRP4), cyclin D1 signalling (CDKN2A, CDKN2B), as well as WT1, RIZ1, RASSF1A and HIC1. ${ }^{141} 152205210-213$ As mentioned previously, cyclin D1 signalling plays an important role in cell cycle progression in parathyroid tissue and can be induced by Wnt/ $\beta$-catenin signalling, another tumorigenesis pathway in many solid tumours. ${ }^{81} 141196212$ 214-216 APC, SFRP1, SFRP2 and SFRP4 genes all serve important regulatory functions in Wnt/ $\beta$-catenin signalling, whereas CDKN2A and CDKN2B genes appear to regulate cyclin D1 signalling. ${ }^{81} 141212$ 214-216 WT1 (Wilms tumour 1) encodes an important transcription factor for cellular development and survival, and mutations in WT1 have

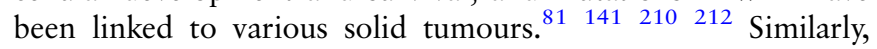
RIZ1 (retinoblastoma-interacting zinc finger gene) appears to be involved in cell cycle regulation. $\begin{array}{lllll}141 & 205 & 210 & 212 & 217 \\ \text { RASSF1A }\end{array}$ (Ras association domain family 1 isoform A; 3p21) is a component in the Ras signalling pathway and has been shown to suppress cyclin D1. ${ }^{218-220}$ HIC1 (17p13) is a putative tumour suppressor gene, epigenetically deregulated in parathyroid tumours due to histone H3 lysine modification. ${ }^{212} 213$ Recently, aberrant expression of a panel of embryonic-related microRNAs has been described in a series of sporadic parathyroid tumours, suggesting a role for microRNA deregulation in parathyroid tumorigenesis. $^{211} 212$

\section{Sporadic parathyroid carcinomas}

In contrast to parathyroid adenomas, parathyroid carcinomas are aggressive sporadic neoplasms, with significant morbidity and mortality related to PTH-mediated hypercalcaemia. 71942475197 Consequently, the study and understanding of their molecular biology is important to uncover novel diagnostic, prognostic and predictive biomarkers to improve patient care. With recent advances in molecular pathology, a wide array of genetic and epigenetic alterations, as well as biomarkers, have been uncovered in parathyroid cancer. $^{42} 98141156158163210216$

Inactivation of CDC73/HRPT2 (1q31.2) and its gene product, parafibromin, is a major driver in parathyroid cancer, appearing in $>70 \%$ of cases in some series. ${ }^{42} 98141156158161$ As mentioned previously, parafibromin serves critical tumour suppressor functions in normal parathyroid tissue, notably by interaction with PAF1 complex and regulating cyclin D1 and Wnt/ $\beta$-catenin signalling. $^{31} 4298141 \quad 156158161221$ It should be noted that decreased expression of parafibromin can occur in rare parathyroid adenomas (often with cystic features; associated with germ-

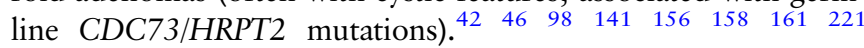
However, complete loss of parafibromin expression, due to bi-allelic inactivating mutations of CDC73/HRPT2, is almost pathognomonic for parathyroid carcinomas as it is almost never seen in adenomas. ${ }^{42} 4698141156158161162$ 221-224 Furthermore, all patients with histologically proven parathyroid carcinomas with loss of parafibromin staining should be considered for genetic testing since up to $20 \%$ of cases may harbour germline mutations in CDC73/HRPT2 with or without clinical features of HPT-JT syndrome. ${ }^{39} 42-4698141156158161162$ 221-224

Additional molecular alterations identified in parathyroid carcinomas (CCND1, CDKIs, MEN1, EZH2, RIZ1, RASSF1, GSK3B, WT1, APC, SFRP, HIC1, CaSR, VDR and microRNA deregulation) are non-specific and can also occur in parathyroid adenomas. ${ }^{31} 42438182141151164205210211212216217219$ Of note, MEN1 mutations, one of the key drivers in parathyroid adenomas $(20-40 \%)$, appear to be less frequent in carcinomas (10-15\%). . $^{31} 4281141225-229$ Recently, whole-genome sequencing uncovered additional mutations in parathyroid carcinomas, implicating PRUNE2 ( 18\%), mTOR, MLL2, THRAP3 and PIK3CA genes. ${ }^{141} 226227$ Overexpression of PGP9.5 (gene product of UCHL1 gene), galectin-3 and TERT (telomerase reverse transcriptase gene) were also described in some parathyroid carcinomas. ${ }^{160} 223230$ Previous comparative genomic hybridisation and molecular allelotyping studies on parathyroid carcinomas also revealed losses on chromosomes $1 \mathrm{p}, 3,13 \mathrm{q}$ and 14 and gains on chromosomes $1 \mathrm{q}$ and $16^{42}{ }^{141}$ Interestingly, some of these loci $(1 p, 13 q, 16)$ were also reported in adenomas. ${ }^{141}{ }^{191}$ Several studies suggest a possible involvement of the $\mathrm{p} 53 / \mathrm{Rb}$ signalling pathway: while TP53 mutations are rare, allelic loss and abnormal expression of p53 and retinoblastoma protein have been uncovered in a subset of parathyroid carcinomas. $^{81} 98141$

\section{TREATMENT AND PROGNOSIS}

The management of HPT depends largely on its aetiology. 14672934353650107231 After excluding reversible secondary aetiologies, first-line treatment of irreversible secondary HPT (often related to chronic kidney disease) mainly involves medical therapies, using low-phosphate diet, phosphate binders, 1,25-dihydroxyvitamin $\mathrm{D}_{3}$ (calcitriol or analogues; to suppress PTH secretion) and/or calcimimetic agent (cinacalcet; an allosteric activator of CaSR). ${ }^{1} 467112934-3650107231232$ In severe cases of secondary HPT refractory to medical treatment or in tertiary HPT, parathyroidectomy can be beneficial for both biochemical abnormalities and symptomatic control. ${ }^{14} 67112934-36507274107$ 231-234

Although percutaneous ethanol ablation may be an alternative to parathyroidectomy in select cases of primary HPT, ${ }^{235} 236$ surgical excision of abnormal 'hyperfunctioning' parathyroid gland (s) remains the only curative treatment. ${ }^{14} 72934-36231$ While symptomatic cases are addressed with parathyroidectomy, surgery in asymptomatic HPT is typically reserved to patients with one of the following conditions: age ( $<50$ years), kidney disease (creatinine clearance $<60 \mathrm{~mL} / \mathrm{min}$; radiographic nephrolithiasis/nephrocalcinosis; 24-h urinary calcium $>400 \mathrm{mg} / \mathrm{d}$ with increased stone risk), bone disease (osteoporosis, ie, bone mineral density $\mathrm{T}$ score $<-2.5$ at distal $1 / 3$ of radius, femoral neck, total hip, lumbar spine; radiographic vertebral fractures), overt hypercalcaemia (serum calcium $>1.0 \mathrm{mg} / \mathrm{dL}$ above upper 
limit of normal) and if routine surveillance is not feasible. $^{1} 472934-36231$

In all cases of primary HPT, an underlying genetic syndrome should be considered, especially if hypocalciuria or multiglandular parathyroid disease is detected. ${ }^{4} 713293042$ In particular, familial hypocalciuric hypercalcaemia should be excluded, using urinary calcium-to-creatinine clearance ratio and/or genetic testing (CASR, GNA11, AP2S1), given the fact that most patients with this condition do not benefit from parathyroidect-

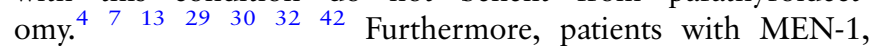
MEN-2A or familial isolated HPT merit closer monitoring, given their increased risk of recurrent/persistent disease due to multig-

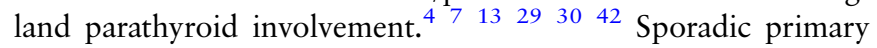
HPT is usually caused by single-gland parathyroid disease, commonly from a solitary adenoma. $\begin{aligned} & 7 \\ & 7\end{aligned} 29303842123$ Minimally invasive parathyroidectomy is an increasingly popular approach, although open surgery with bilateral cervical exploration is still advocated by some endocrine surgeons, particularly in multigland disease and/or recurrent HPT. ${ }^{4} 13293042123$ The complete removal of abnormal parathyroid tissue should be confirmed biochemically with intraoperative (or postoperative) PTH measure-

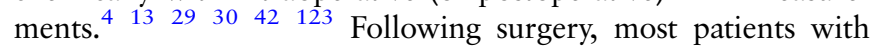
clinically and pathologically confirmed parathyroid adenoma are cured. $^{46713293042123}$

In parathyroid carcinomas, an oncological surgical approach, including at least en bloc resection (either as a primary or revision surgery), is paramount for disease control. ${ }^{29} 3647519497$ Adjuvant radiation has been proposed to decrease local recurrence rate, although this approach remains controversial. ${ }^{47} 519497$ Given its rarity, challenging diagnosis and high-risk of recurrence, suspected cases of parathyroid carcinomas should be referred to endocrinologists, surgeons and pathologists with extensive experience in endocrine oncology. ${ }^{29} 3647519497$ At our institution, in a cohort of 16 patients with parathyroid cancer, the 5-year and 10-year disease-specific survival rates were $100 \%$ and $80 \%$, respectively; the 5 -year and 10 -year disease-free survival rates were $69 \%$ and $43 \% .{ }^{97}$ These findings confirm the relatively indolent behaviour of parathyroid malignancies reported in the literature, while reinforcing the high risk of disease recurrence, which can occur many years after initial treatment. 475194

In patients diagnosed with a parathyroid carcinoma, the tumour should be further tested for loss of parafibromin expression. $^{42} 47 \quad 158159161162$ Those showing loss of immunohistochemical parafibromin expression should be offered genetic testing for germline CDC73/HRPT2 mutations. ${ }^{42} 47158162$ In patients with primary HPT who cannot or do not want to undergo surgery, ethanol injection and alternative treatment modalities remain limited at this time. ${ }^{47} 51$ Emerging medical therapies, similar to those used in secondary HPT, have been shown to be beneficial, although not curative, in a subset of patients. ${ }^{147231232237-241}$

\section{CONCLUSION}

HPT is a common, morbid yet fascinating disorder in the evolving field of endocrinology. Clinicopathological correlates of primary HPT include parathyroid adenoma (80-85\%), hyperplasia $(10-15 \%)$ and carcinoma $(<1-5 \%)$. The clinical and biochemical history, including intraoperative PTH measurements, number, size and weight of the affected gland(s), are crucial parameters to consider when rendering a clinicopathological diagnosis of parathyroid proliferations. Ultimately, the role of the pathologist pertains to the accurate distinction between single-gland (usually a solitary parathyroid adenoma) and multigland disease (diffuse and/or nodular parathyroid hyperplasia), all the while excluding a primary parathyroid malignancy. New developments in diagnostic imaging and intraoperative rapid PTH assays have substantially improved our ability to distinguish between single-gland and multigland parathyroid disease preoperatively. These findings have tremendous implications on the prognosis of the patient, as well as the need to pursue further genetic testing, clinical monitoring and/or adjuvant therapies. ${ }^{242}$ In addition, important mechanisms underlying the molecular biology of HPT have been elucidated with the discovery of genetic and epigenetic alterations implicating cyclin D1 signalling (CCND1/PRAD1, CDC73/HRPT2, CDKN1B, CDKIs, ZFX), Wnt/ $\beta$-catenin signalling (MEN1, APC, EZH2, CTNNB1, SFRPs) and CaSR signalling (CaSR, GNA11, AP2S1), offering promising targets for the development of new diagnostic, prognostic and predictive biomarkers.

\section{Take home messages}

- Pathological correlations of hyperparathyroidism include parathyroid hyperplasia, adenoma and carcinoma.

- The primary role of the intraoperative pathological consultation is to confirm the presence of parathyroid tissue in the resected specimen and to confirm the presence of abnormal (enlarged cellular) gland.

- Clinical and biochemical features, including intraoperative PTH levels, number, weight and size of the affected parathyroid gland(s), are crucial parameters to consider when rendering an accurate diagnosis of parathyroid proliferations.

- The diagnosis of parathyroid carcinoma is rendered when a parathyroid neoplasm exhibits any of the followings: vascular invasion, perineural invasion, invasive growth into adjacent structures/organs, and/or metastasis.

- The application of ancillary tools can also help to distinguish benign disease from parathyroid carcinoma. In particular, the use of parafibromin immunostain is very helpful to differentiate between parathyroid adenomas (intact nuclear and nucleolar parafibromin expression) and parathyroid carcinomas (complete loss of nuclear or nucleolar parafibromin expression.

- Genetic and epigenetic alterations resulting in deregulation of cyclin D1, Wnt/ $\beta$-catenin and CaSR signalling have been uncovered in a significant subset of patients with primary hyperparathyroidism.

- In the absence of secondary causes of hyperparathyroidism, an underlying familial syndrome should be considered in patients with parathyroid hyperplasia and carcinoma, which may be found in respectively $\sim 25 \%$ and $\sim 15 \%$ of cases.

\section{Handling editor Runjan Chetty}

Contributors OM: substantial contributions to the conception or design of the work; or the acquisition, analysis or interpretation of data for the work; final approval of the version to be published; agreement to be accountable for all aspects of the work in ensuring that questions related to the accuracy or integrity of any part of the work are appropriately investigated and resolved. $\mathrm{KD}, \mathrm{KGH}$ and $\mathrm{OM}$ : drafting the work or revising it critically for important intellectual content.

Competing interests None declared.

Provenance and peer review Commissioned; internally peer reviewed. 


\section{REFERENCES}

1 Bilezikian JP, Brandi ML, Eastell R, et al. Guidelines for the management of asymptomatic primary hyperparathyroidism: summary statement from the fourth international workshop. J Clin Endocrinol Metab 2014;99:3561-9.

2 Bilezikian JP, Silverberg SJ. Normocalcemic primary hyperparathyroidism. Arq Bras Endocrinol Metabol 2010;54:106-9.

3 Bilezikian JP, Marcus R, Levine MA, et al. The parathyroids: basic and clinical concepts. Academic Press, 2014.

4 Marcocci C, Cetani F. Clinical practice. Primary hyperparathyroidism. N Engl J Med 2011:365:2389-97.

5 Mackenzie-Feder J, Sirrs S, Anderson D, et al. Primary hyperparathyroidism: an overview. Int J Endocrinol 2011:2011:251410.

6 Silverberg SJ, Bilezikian JP. The diagnosis and management of asymptomatic primary hyperparathyroidism. Nat Clin Pract Endocrinol Metab 2006;2: 494-503.

7 Fraser WD. Hyperparathyroidism. Lancet 2009;374:145-58.

8 Blanchard C, Mirallié E, Mathonnet M. Sporadic primary hyperparathyroidism. J Visc Surg 2010;147:e285-95.

9 Sociedade Brasileira de Endocrinologia e MetabologiaBandeira F, Griz L, Chaves N, et al. Diagnosis and management of primary hyperparathyroidism - a scientific statement from the Department of Bone Metabolism, the Brazilian Society for Endocrinology and Metabolism. Arq Bras Endocrinol Metabol 2013;57:406-24.

10 Cunningham J, Locatelli F, Rodriguez M. Secondary hyperparathyroidism: pathogenesis, disease progression, and therapeutic options. Clin J Am Soc Nephrol CJASN 2011;6:913-21.

11 Jamal SA, Miller PD. Secondary and tertiary hyperparathyroidism. J Clin Densitom 2013;16:64-8.

12 Silverberg SJ, Walker MD, Bilezikian JP. Asymptomatic primary hyperparathyroidism. J Clin Densitom 2013;16:14-21.

13 Eastell R, Brandi ML, Costa AG, et al. Diagnosis of asymptomatic primary hyperparathyroidism: proceedings of the fourth international workshop. J Clin Endocrinol Metab 2014:99:3570-9.

14 Silverberg SJ, Clarke BL, Peacock M, et al. Current issues in the presentation of asymptomatic primary hyperparathyroidism: proceedings of the fourth international workshop. J Clin Endocrinol Metab 2014;99:3580-94.

15 Walker MD, Rubin M, Silverberg SJ. Nontraditional manifestations of primary hyperparathyroidism. J Clin Densitom 2013;16:40-7.

16 Bandeira F, Cusano NE, Silva BC, et al. Bone disease in primary hyperparathyroidism. Arq Bras Endocrinol Metabol 2014;58:553-61.

17 Silva BC, Boutroy S, Zhang C, et al. Trabecular bone score (TBS) - a novel method to evaluate bone microarchitectural texture in patients with primary hyperparathyroidism. J Clin Endocrinol Metab 2013;98:1963-70.

18 Lewiecki EM, Miller PD. Skeletal effects of primary hyperparathyroidism: bone mineral density and fracture risk. J Clin Densitom 2013;16:28-32.

19 Marcocci C, Cianferotti L, Cetani F. Bone disease in primary hyperparathyrodism. Ther Adv Musculoskelet Dis 2012:4:357-68.

20 Grant $P$, Velusamy $A$. What is the best way of assessing neurocognitive dysfunction in patients with primary hyperparathyroidism? J Clin Endocrinol Metab 2014;99:49-55

21 Fitzpatrick LA, Bilezikian JP, Silverberg SJ. Parathyroid hormone and the cardiovascular system. Curr Osteoporos Rep 2008;6:77-83.

22 Clifton-Bligh PB, Nery ML, Supramaniam R, et al. Mortality associated with primary hyperparathyroidism. Bone 2015;74C:121-4.

23 Walker MD, Silverberg SJ. Cardiovascular aspects of primary hyperparathyroidism. J Endocrinol Invest 2008;31:925-31.

24 Chen $G$, Xue $Y$, Zhang Q, et al. Is normocalcemic primary hyperparathyroidism harmful or harmless? J Clin Endocrinol Metab 2015:100:2420-4.

25 Walker MD, Cong E, Kepley A, et al. Association between serum 25-hydroxyvitamin D level and subclinical cardiovascular disease in primary hyperparathyroidism. J Clin Endocrinol Metab 2014;99:671-80.

26 Clarke BL. Epidemiology of primary hyperparathyroidism. J Clin Densitom 2013;16:8-13.

27 Griebeler $M L$, Kearns $A E$, Ryu $E$, et al. Secular trends in the incidence of primary hyperparathyroidism over five decades (1965-2010). Bone 2015;73:1-7.

28 Yeh MW, Ituarte PHG, Zhou HC, et al. Incidence and prevalence of primary hyperparathyroidism in a racially mixed population. J Clin Endocrinol Metab 2013:98:1122-9.

29 Udelsman R, Åkerström G, Biagini C, et al. The surgical management of asymptomatic primary hyperparathyroidism: proceedings of the fourth international workshop. J Clin Endocrinol Metab 2014;99:3595-606.

30 Giusti F, Cavalli L, Cavalli T, et al. Hereditary hyperparathyroidism syndromes. J Clin Densitom 2013;16:69-74.

31 Arnold A, Lauter K. Chapter 12-genetics of hyperparathyroidism including parathyroid cancer. In: Refetoff REW, ed. Genetic diagnosis of endocrine disorders. San Diego: Academic Press, 2010:141-8. http://www.sciencedirect.com/science/ article/pii/B9780123744302000122 (accessed 8 Feb 2015).

32 Arnold A, Marx SJ. Familial hyperparathyroidism (Including MEN, FHH, and HPTJT). In: Rosen, CJ, ed. Primer on the Metabolic Bone Diseases and Mineral
Metabolism, 7th ed. Washington, D.C.: American Society of Bone and Mineral Research; 2009:361-7.

33 Arnold A, Shattuck TM, Mallya SM, et al. Molecular pathogenesis of primary hyperparathyroidism. J Bone Miner Res 2002;17(Suppl 2):N30-6.

34 Callender GG, Udelsman R. Surgery for primary hyperparathyroidism. Cancer 2014;120:3602-16.

35 Dowthwaite SA, Young JE, Pasternak JD, et al. Surgical management of primary hyperparathyroidism. J Clin Densitom 2013;16:48-53.

36 Van Udelsman B, Udelsman R. Surgery in primary hyperparathyroidism: extensive personal experience. J Clin Densitom 2013;16:54-9.

37 Lew JI, Solorzano CC. Surgical management of primary hyperparathyroidism: state of the art. Surg Clin North Am 2009:89:1205-25.

38 Carlson D. Parathyroid pathology: hyperparathyroidism and parathyroid tumors Arch Pathol Lab Med 2010;134:1639-44.

39 Baloch ZW, LiVolsi VA. Pathology of the parathyroid glands in hyperparathyroidism Semin Diagn Pathol 2013;30:165-77.

40 Baloch ZW, LiVolsi VA. Parathyroid glands, pathology $\star$. In: Reference Module in Biomedical Sciences. Elsevier, 2014. http://www.sciencedirect.com/science/article/ pii/B978012801238303782X (accessed 8 Feb 2015)

41 LiVolsi VA, Montone KT, Baloch ZN. Parathyroid. Surg Pathol Clin 2014;7:515-31.

42 DeLellis RA. Parathyroid tumors and related disorders. Mod Pathol Off J U S Can Acad Pathol Inc 2011;24(Suppl 2):S78-93.

43 DeLellis RA. Challenging lesions in the differential diagnosis of endocrine tumors: parathryoid carcinoma. Endocr Pathol 2008;19:221-5.

44 DeLellis RA. Tumors of the parathyroid gland. In: Atlas of tumor pathology. 3rd series, fascicle 6. Washington DC: Armed Forces Institute of Pathology, 1993.

45 Van der Walt J. Pathology of the parathyroid glands. Diagn Histopathol 2012;18:221-33.

46 DeLellis RA, Mazzaglia P, Mangray S. Primary hyperparathyroidism: a current perspective. Arch Pathol Lab Med 2008;132:1251-62.

47 Betea D, Potorac I, Beckers A. Parathyroid carcinoma: challenges in diagnosis and treatment. Ann Endocrinol (Paris). 2015;76:169-77.

48 DÁbrowska A, Tarach J, Zwolak A. [Primary hyperparathyroidism due to parathyroid cancer - a diagnostic and management challenge]. Endokrynol Pol 2015:66:150-67.

49 Do Cao C, Aubert S, Trinel C, et al. Parathyroid carcinoma: Diagnostic criteria, classification, evaluation. Ann Endocrinol (Paris) 2015;76:165-8.

50 Davies M, Fraser WD, Hosking DJ. The management of primary hyperparathyroidism. Clin Endocrinol (Oxf) 2002;57:145-55.

51 Schulte K-M, Talat N. Diagnosis and management of parathyroid cancer. Nat Rev Endocrinol 2012;8:612-22.

52 Haglund $F$, Ma R, Huss $M$, et al. Evidence of a functional estrogen receptor in parathyroid adenomas. J Clin Endocrinol Metab 2012;97:4631-9.

53 Haglund F, Rosin G, Nilsson I-L, et al. Tumour nuclear oestrogen receptor beta 1 correlates inversely with parathyroid tumour weight. Endocr Connect 2015:4:76-85

54 Silverberg SJ, Lewiecki EM, Mosekilde L, et al. Presentation of asymptomatic primary hyperparathyroidism: proceedings of the third international workshop. J Clin Endocrinol Metab 2009;94:351-65.

55 Lundstam K, Heck A, Mollerup C, et al. Effects of parathyroidectomy versus observation on the development of vertebral fractures in mild primary hyperparathyroidism. J Clin Endocrinol Metab 2015;100:1359-67.

56 Cipriani C, Bilezikian JP. Commentary on silent renal stones in primary hyperparathyroidism: prevalence and clinical features. Endocr Pract 2014:20:1231-3.

57 Macfarlane DP, Yu N, Leese GP. Asymptomatic and mild primary hyperparathyroidism. Ann Endocrinol 2015;76:120-7.

58 Macfarlane DP, Yu N, Leese GP. Subclinical and asymptomatic parathyroid disease: implications of emerging data. Lancet Diabetes Endocrinol 2013:1:329-40.

59 Cipriani C, Biamonte F, Costa AG, et al. Prevalence of kidney stones and vertebral fractures in primary hyperparathyroidism using imaging technology. J Clin Endocrinol Metab 2015;100:1309-15.

60 Costa AG, Bilezikian JP. Bone turnover markers in primary hyperparathyroidism. J Clin Densitom 2013:16:22-7.

61 Bilezikian JP, Brandi ML, Rubin M, et al. Primary hyperparathyroidism: new concepts in clinical, densitometric and biochemical features. J Intern Med 2005:257:6-17.

62 Rubin MR, Bilezikian JP, McMahon DJ, et al. The natural history of primary hyperparathyroidism with or without parathyroid surgery after 15 years. J Clin Endocrinol Metab 2008;93:3462-70.

63 Ludvigsson JF, Kämpe 0, Lebwohl B, et al. Primary hyperparathyroidism and celiac disease: a population-based cohort study. J Clin Endocrinol Metab 2012;97:897-904.

64 Silverberg SJ. Non-classical target organs in primary hyperparathyroidism. J Bone Miner Res 2002;17(Suppl 2):N117-25.

65 Bandeira F, Gharib H, Golbert A, et al. Endocrinology and diabetes: a problem-oriented approach. Springer Science \& Business Media, 2013.

66 Brickman AS, Massry SG, Coburn JW. changes in serum and urinary calcium during treatment with hydrochlorothiazide: studies on mechanisms. J Clin Invest 1972;51:945-54. 
67 Lehmann SW, Lee J. Lithium-associated hypercalcemia and hyperparathyroidism in the elderly: what do we know? J Affect Disord 2013;146:151-7.

68 Touvier M, Deschasaux M, Montourcy M, et al. Interpretation of plasma PTH concentrations according to $250 \mathrm{HD}$ status, gender, age, weight status, and calcium intake: importance of the reference values. J Clin Endocrinol Metab 2014:99:1196-203.

69 Cusano NE, Silverberg SJ, Bilezikian JP. Normocalcemic primary hyperparathyroidism. J Clin Densitom 2013;16:33-9.

70 Souberbielle J-C, Cavalier E, Cormier C. How to manage an isolated elevated PTH? Ann Endocrinol 2015:76:134-41.

71 Pipili C, Sekecioglu N, Oreopoulos DG. Normocalcemic hyperparathyroidism in patients with recurrent kidney stones: a disease entity or vitamin $\mathrm{D}$ deficiency? Clin Nephrol 2012;77:352-7.

72 Kidney Disease: Improving Global Outcomes (KDIGO) CKD-MBD Work Group. KDIGO clinical practice guideline for the diagnosis, evaluation, prevention, and treatment of Chronic Kidney Disease-Mineral and Bone Disorder (CKD-MBD). Kidney Int Supp/ 2009;(113):S1-130.

73 Coe FL, Canterbury JM, Firpo JJ, et al. Evidence for secondary hyperparathyroidism in idiopathic hypercalciuria. J Clin Invest 1973;52:134-42.

74 Rodriguez M, Canalejo A, Garfia B, et al. Pathogenesis of refractory secondary hyperparathyroidism. Kidney Int Supp/ 2002;(80):155-60.

75 Eldeiry LS, Ruan DT, Brown EM, et al. Primary hyperparathyroidism and familial hypocalciuric hypercalcemia: relationships and clinical implications. Endocr Pract 2012:18:412-17.

76 Mrgan M, Nielsen S, Brixen K. Familial hypocalciuric hypercalcemia and calcium sensing receptor. Acta Clin Croat 2014;53:220-5.

77 Hendy GN, Cole DEC. Genetic defects associated with familial and sporadic hyperparathyroidism. Front Horm Res 2013;41:149-65.

78 Cetani F, Pardi E, Borsari S, et al. Molecular pathogenesis of primary hyperparathyroidism. J Endocrinol Invest 2011;34(7 Suppl):35-9.

79 Pepe J, Cipriani C, Pilotto R, et al. Sporadic and hereditary primary hyperparathyroidism. J Endocrinol Invest 2011;34(7 Suppl):40-4.

80 Sharretts JM, Simonds WF. Clinical and molecular genetics of parathyroid neoplasms. Best Pract Res Clin Endocrinol Metab 2010;24:491-502.

81 Segiet OA, Deska M, Michalski M, et al. Molecular profiling in primary hyperparathyroidism. Head Neck 2015;37:299-307.

82 Westin G, Björklund P, Åkerström G. Molecular genetics of parathyroid disease. World J Surg 2009;33:2224-33.

83 Marx SJ, Simonds WF, Agarwal SK, et al. Hyperparathyroidism in hereditary syndromes: special expressions and special managements. J Bone Miner Res 2002;17(Suppl 2):N37-43.

84 Agarwal SK. Multiple endocrine neoplasia type 1. Front Horm Res 2013;41:1-15.

85 Thakker RV. Multiple endocrine neoplasia type 1 (MEN1) and type 4 (MEN4). Mol Cell Endocrinol 2014;386:2-15.

86 Thakker RV, Newey PJ, Walls GV, et al. Clinical practice guidelines for multiple endocrine neoplasia type 1 (MEN1). J Clin Endocrinol Metab 2012;97:2990-3011.

87 Guarnieri V, Canaff L, Yun FHJ, et al. Calcium-sensing receptor (CASR) mutations in hypercalcemic states: studies from a single endocrine clinic over three years. J Clin Endocrinol Metab 2010;95:1819-29.

88 Li D, Opas EE, Tuluc F, et al. Autosomal dominant hypoparathyroidism caused by germline mutation in GNA11: phenotypic and molecular characterization. J Clin Endocrinol Metab 2014;99:E1774-83.

89 Rogers A, Nesbit MA, Hannan FM, et al. Mutational analysis of the adaptor protein 2 sigma subunit (AP2S1) gene: search for autosomal dominant hypocalcemia type 3 (ADH3). J Clin Endocrinol Metab 2014;99:E1300-5.

90 Hendy GN, Canaff L, Newfield RS, et al. Codon Arg15 mutations of the AP2S1 gene: common occurrence in familial hypocalciuric hypercalcemia cases negative for calcium-sensing receptor (CASR) mutations. J Clin Endocrinol Metab 2014;99: E1311-15.

91 Nesbit MA, Hannan FM, Howles SA, et al. Mutations in AP2S1 cause familial hypocalciuric hypercalcemia type 3. Nat Genet 2013;45:93-7.

92 Pallauf A, Schopohl J, Makeschin M, et al. Lethal generalized calcinosis and hypercalcemic crisis in primary hyperparathyroidism. J Clin Endocrinol Metab 2015;100:17-18.

93 Villar-del-Moral J, Jiménez-García A, Salvador-Egea P, et al. Prognostic factors and staging systems in parathyroid cancer: a multicenter cohort study. Surgery 2014:156:1132-44.

94 Schulte KM, Talat N, Galata G, et al. Oncologic resection achieving r0 margins improves disease-free survival in parathyroid cancer. Ann Surg Oncol 2014;21:1891-7.

95 Schulte K-M, Gill AJ, Barczynski M, et al. Classification of parathyroid cancer. Ann Surg Oncol 2012;19:2620-8.

96 Talat N, Schulte K-M. Clinical presentation, staging and long-term evolution of parathyroid cancer. Ann Surg Oncol 2010;17:2156-74.

97 Erovic BM, Goldstein DP, Kim D, et al. Parathyroid cancer: outcome analysis of 16 patients treated at the Princess Margaret Hospital. Head Neck 2013;35:35-9.
98 Erovic BM, Harris L, Jamali M, et al. Biomarkers of parathyroid carcinoma. Endocr Pathol 2012:23:221-31.

99 Mete O, Asa SL, eds. Endocrine pathology. Cambridge University Press, 2016.

100 Wei $\mathrm{CH}$, Harari A. Parathyroid carcinoma: update and guidelines for management. Curr Treat Options Oncol 2012;13:11-23.

101 Kassahun WT, Jonas S. Focus on parathyroid carcinoma. Int I Surg Lond Engl 2011;9:13-19.

102 Al-Kurd A, Mekel M, Mazeh H. Parathyroid carcinoma. Surg Oncol 2014;23:107-14.

103 Cavalier E, Betea D, Schleck M-L, et al. The third/second generation PTH assay ratio as a marker for parathyroid carcinoma: evaluation using an automated platform. J Clin Endocrinol Metab 2014;99:E453-7.

104 Cavalier E, Delanaye P, Nyssen L, et al. Problems with the PTH assays. Ann Endocrinol 2015;76:128-33.

105 Rubin MR, Silverberg SJ, D'Amour P, et al. An N-terminal molecular form of parathyroid hormone (PTH) distinct from $\mathrm{hPTH}(184)$ is overproduced in parathyroid carcinoma. Clin Chem 2007:53:1470-6.

106 Treglia G, Sadeghi R, Schalin-Jäntii C, et al. Detection rate of (99 m) Tc-MIBI SPECT/CT in the preoperative planning of patients with primary hyperparathyroidism: a meta-analysis. Head Neck Published Online First: 9 Mar 2015 doi:10.1002/hed.24027

107 Kunstman JW, Kirsch JD, Mahajan A, et al. Clinical review: Parathyroid localization and implications for clinical management. J Clin Endocrinol Metab 2013:98:902-12

108 Guerin C, Lowery A, Gabriel S, et al. Preoperative imaging for focused parathyroidectomy: making a good strategy even better. Eur J Endocrinol 2015; 172:519-26.

109 Silverberg SJ, Locker FG, Bilezikian JP. Vertebral osteopenia: a new indication for surgery in primary hyperparathyroidism. J Clin Endocrinol Metab 1996;81:4007-12.

110 Yang Q, Sun P, Li J, et al. Skeletal lesions in primary hyperparathyroidism. Am J Med Sci 2015:349:321-7.

111 Elgazzar AH, Alenezi SA. Parathyroid Gland. In: Elgazzar AH, ed. The pathophysiologic basis of nuclear medicine. Springer International Publishing, 2015:281-303. http://link.springer.com.myaccess.library.utoronto.ca/chapter/10. 1007/978-3-319-06112-2_8 (accessed 8 Mar 2015).

112 Michaud L, Burgess A, Huchet $V$, et al. Is 18F-fluorocholine-positron emission tomography/computerized tomography a new imaging tool for detecting hyperfunctioning parathyroid glands in primary or secondary hyperparathyroidism? J Clin Endocrinol Metab 2014;99:4531-6.

113 Hindié $E$, Zanotti-Fregonara $\mathrm{P}$, Tabarin $\mathrm{A}$, et al. The role of radionuclide imaging in the surgical management of primary hyperparathyroidism. J Nucl Med Off Pub/ Soc Nucl Med 2015:56:737-44.

114 Wong KK, Fig LM, Gross MD, et al. Parathyroid adenoma localization with 99mTc sestamibi SPECT/CT: a meta-analysis. Nucl Med Commun 2015;36:363-75.

115 Wimmer G, Profanter C, Kovacs P, et al. CT-MIBI-SPECT image fusion predicts multiglandular disease in hyperparathyroidism. Langenbecks Arch Surg 2010:395:73-80.

116 Philip M, Guerrero MA, Evans DB, et al. Efficacy of 4D-CT preoperative localization in 2 patients with MEN 2A. J Surg Educ 2008;65:182-5.

117 Shepherd JJ, Burgess JR, Greenaway TM, et al. Preoperative sestamibi scanning and surgical findings at bilateral, unilateral, or minimal reoperation for recurrent hyperparathyroidism after subtotal parathyroidectomy in patients with multiple endocrine neoplasia type 1. Arch Surg Chic III 1960 2000;135:844-8.

118 Mohebati A, Shaha AR. Imaging techniques in parathyroid surgery for primary hyperparathyroidism. Am J Otolaryngol 2012;33:457-68.

119 Phillips CD, Shatzkes DR. Imaging of the parathyroid glands. Semin Ultrasound CT MRI 2012;33:123-9

120 Grimelius L, Akerström G, Bondeson L, et al. The role of the pathologist in diagnosis and surgical decision making in hyperparathyroidism. World I Surg 1991;15:698-705.

121 Mete 0, Rotstein L, Asa SL. Controversies in thyroid pathology: thyroid capsule invasion and extrathyroidal extension. Ann Surg Oncol 2010;17:386-91.

122 Wieneke JA, Smith A. Parathyroid Adenoma. Head Neck Pathol 2008:2:305-8.

123 DeLellis RA. Pathology and genetics of tumours of endocrine organs. IARC, 2004.

124 Osamura RY, Hunt JL. Current practices in performing frozen sections for thyroid and parathyroid pathology. Virchows Arch Int J Pathol 2008;453: 433-40.

125 Wei S, LiVolsi VA, Baloch ZW. Images in endocrine pathology: parathyroid adenoma with frozen section artifact mimics thyroid papillary carcinoma. Endocr Pathol 2015;26:185-6.

126 Dufour DR, Durkowski C. Sudan IV stain. Its limitations in evaluating parathyroid functional status. Arch Pathol Lab Med 1982:106:224-7.

127 Vignali E, Picone A, Materazzi G, et al. A quick intraoperative parathyroid hormone assay in the surgical management of patients with primary hyperparathyroidism: a study of 206 consecutive cases. Eur J Endocrinol Eur Fed Endocr Soc 2002;146:783-8. 
128 Di Stasio E, Carrozza C, Pio Lombardi C, et al. Parathyroidectomy monitored by intra-operative PTH: the relevance of the 20 min end-point. Clin Biochem 2007; 40:595-603.

129 Udelsman R, Donovan P, Shaw C. Cure predictability during parathyroidectomy. World I Surg 2014;38:525-33.

130 Barczynski M, Konturek A, Hubalewska-Dydejczyk A, et al. Evaluation of Halle, Miami, Rome, and Vienna intraoperative iPTH assay criteria in guiding minimally invasive parathyroidectomy. Langenbecks Arch Surg 2009;394:843-9.

131 Parathyroid Pathology: A Practical Approach: Pathology Case Reviews. LWW. http:/l journals.Iww.com/pathologycasereviews/Fulltext/2003/01000/Parathyroid_ Pathology_A_Practical_Approach.6.aspx (accessed 29 May 2015).

132 Baloch ZW, LiVolsi VA. Double adenoma of the parathyroid gland tumors. Arch Pathol Lab Med 2001;125:178-9.

133 Alwaheeb S, Rambaldini G, Boerner S, et al. Worrisome histologic alterations following fine-needle aspiration of the parathyroid. J Clin Pathol 2006;59:1094-6.

134 Wong KS, Lewis JS, Gottipati S, et al. Utility of birefringent crystal identification by polarized light microscopy in distinguishing thyroid from parathyroid tissue on intraoperative frozen sections. Am J Surg Pathol 2014;38:1212-19.

135 Abbona GC, Papotti M, Gasparri G, et al. Proliferative activity in parathyroid tumors as detected by Ki-67 immunostaining. Hum Pathol 1995;26:135-8.

136 Bai S, LiVolsi VA, Fraker DL, et al. Water-Clear Parathyroid Adenoma: Report of Two Cases and Literature Review. Endocr Pathol 2012;23:196-200.

137 Murakami K, Watanabe M, Nakashima N, et al. Water-clear cell adenoma associated with primary hyperparathyroidism: report of a case. Surg Today 2014;44:773-7.

138 Piggott RP, Waters PS, Ashraf J, et al. Water-clear cell adenoma: a rare form of hyperparathyroidism. Int I Surg Case Rep 2013;4:911-13.

139 Ezzat T, Maclean G, Parameswaran R, et al. Primary hyperparathyroidism with water clear cell content: the impact of histological diagnosis on clinical management and outcome. Ann R Coll Surg Engl 2013;95:e60-2.

140 Alhefdhi A, Schneider DF, Sippel R, et al. Recurrent and persistence primary hyperparathyroidism occurs more frequently in patients with double adenomas. J Surg Res 2014;190:198-202.

141 Costa-Guda J, Arnold A. Genetic and epigenetic changes in sporadic endocrine tumors: parathyroid tumors. Mol Cell Endocrinol 2014;386:46-54.

142 Gasparri G, Camandona M, Abbona GC, et al. Secondary and tertiary hyperparathyroidism: causes of recurrent disease after 446 parathyroidectomies. Ann Surg 2001;233:65-9.

143 Mete 0, Asa SL. Precursor lesions of endocrine system neoplasms. Pathology (Phila) 2013;45:316-30.

144 Friedman E, Sakaguchi K, Bale AE, et al. Clonality of Parathyroid Tumors in Familial Multiple Endocrine Neoplasia Type 1. N Engl J Med 1989;321:213-18.

145 Marx SJ. Multiplicity of hormone-secreting tumors: common themes about cause, expression, and management. J Clin Endocrinol Metab 2013;98:3139-48.

146 Tominaga Y, Kohara S, Namii Y, et al. Clonal analysis of nodular parathyroid hyperplasia in renal hyperparathyroidism. World I Surg 1996;20:744-50; discussion 750-752.

147 Khan MW, Worcester EM, Straus FH, et al. Parathyroid carcinoma in secondary and tertiary hyperparathyroidism1. J Am Coll Surg 2004;199:312-19.

148 Nasrallah MP, Fraker DL, LiVolsi VA. parathyroid carcinoma in the setting of tertiary hyperparathyroidism after renal transplant. Endocr Pathol 2013;25:433-5.

149 Grzela T, Chudzinski W, Lasiecka Z, et al. The calcium-sensing receptor and vitamin D receptor expression in tertiary hyperparathyroidism. Int I Mol Med 2006;17:779-83.

150 Yano S, Sugimoto T, Tsukamoto T, et al. Association of decreased calcium-sensing receptor expression with proliferation of parathyroid cells in secondary hyperparathyroidism. Kidney Int 2000;58:1980-6.

151 Hofman-Bang J, Gravesen E, Olgaard K, et al. Epigenetic methylation of parathyroid $C a R$ and $V D R$ promoters in experimental secondary hyperparathyroidism. Int I Nephrol 2012;2012:e123576.

152 Varshney S, Bhadada SK, Sachdeva N, et al. Methylation status of the CpG Islands in vitamin $\mathrm{d}$ and calcium-sensing receptor gene promoters does not explain the reduced gene expressions in parathyroid adenomas. I Clin Endocrinol Metab 2013:98:E1631-5.

153 Duan K, Mete O. Parathyroid carcinoma: diagnosis and clinical implications. Turk $J$ Pathol. In press.

154 Bondeson L, Sandelin K, Grimelius L. Histopathological variables and DNA cytometry in parathyroid carcinoma. Am J Surg Pathol 1993;17:820-9.

155 Kruijff S, Sidhu SB, Sywak MS, et al. Negative parafibromin staining predicts malignant behavior in atypical parathyroid adenomas. Ann Surg Oncol 2013;21:426-33.

156 Juhlin CC, Nilsson I-L, Johansson K, et al. Parafibromin and APC as screening markers for malignant potential in atypical parathyroid adenomas. Endocr Pathol 2010;21:166-77.

157 Fernandez-Ranvier GG, Khanafshar E, Jensen $\mathrm{K}$, et al. Parathyroid carcinoma, atypical parathyroid adenoma, or parathyromatosis? Cancer 2007;110:255-64.

158 Gill AJ. Understanding the genetic basis of parathyroid carcinoma. Endocr Pathol 2014;25:30-4.
159 Juhlin CC, Haglund F, Obara T, et al. Absence of nucleolar parafibromin immunoreactivity in subsets of parathyroid malignant tumours. Virchows Arch Int $\mathrm{J}$ Pathol 2011;459:47-53.

160 Truran PP, Johnson SJ, Bliss RD, et al. Parafibromin, Galectin-3, PGP9.5, Ki67, and Cyclin D1: using an immunohistochemical panel to aid in the diagnosis of parathyroid cancer. World I Surg 2014;38:2845-54.

161 Juhlin CC, Höög A. Parafibromin as a diagnostic instrument for parathyroid carcinoma-lone ranger or part of the posse? Int I Endocrinol 2010;2010:324964.

162 Cetani F, Banti C, Pardi E, et al. CDC73 mutational status and loss of parafibromin in the outcome of parathyroid cancer. Endocr Connect 2013;2:186-95.

163 Simonds WF. Parathyroid cancer and the CDC73 tumor suppressor gene. Int J Endocr Oncol 2014;1:59-69.

164 Juhlin CC, Haglund F, Villablanca A, et al. Loss of expression for the Wnt pathway components adenomatous polyposis coli and glycogen synthase kinase 3-beta in parathyroid carcinomas. Int I Oncol 2009;34:481-92.

165 Erickson LA. Parathyromatosis. In: Atlas of endocrine pathology. Atlas of anatomic pathology. New York: Springer, 2014:139-41. http://link.springer.com/chapter/10. 1007/978-1-4939-0443-3_18 (accessed 30 May 2015).

166 Shi Y, Hogue J, Dixit D, et al. Functional and genetic studies of isolated cells from parathyroid tumors reveal the complex pathogenesis of parathyroid neoplasia. Proc Natl Acad Sci 2014;111:3092-7.

167 Marx SJ. Uncoupling of secretion from growth in some hormone secretory tissues. J Clin Endocrinol Metab 2014;99:4051-9.

168 Alfadda TI, Saleh AMA, Houillier P, et al. Calcium-sensing receptor 20 years later. Am J Physiol Cell Physiol 2014;307:C221-31.

169 Brown EM. Clinical lessons from the calcium-sensing receptor. Nat Rev Endocrinol 2007;3:122-33.

170 Brennan SC, Thiem U, Roth S, et al. Calcium sensing receptor signalling in physiology and cancer. Biochim Biophys Acta 2013;1833:1732-44.

171 Corbetta S, Mantovani G, Lania A, et al. Calcium-sensing receptor expression and signalling in human parathyroid adenomas and primary hyperplasia. Clin Endocrinol (Oxf) 2000;52:339-48.

172 Sudhaker Rao D, Han ZH, Phillips ER, et al. Reduced vitamin D receptor expression in parathyroid adenomas: implications for pathogenesis. Clin Endocrinol (Oxf) 2000;53:373-81.

173 Costa-Guda J, Soong C-P, Parekh VI, et al. Germline and somatic mutations in cyclin-dependent kinase inhibitor genes CDKN1A, CDKN2B, and CDKN2C in sporadic parathyroid adenomas. Horm Cancer 2013;4:301-7.

174 Duan K, Hernandez KG, Mete O. Clinicopathological correlates of adrenal Cushing's syndrome. J Clin Pathol 2015;68:175-86.

175 Cao $Y$, Liu R, Jiang $X$, et al. Nuclear-cytoplasmic shuttling of menin regulates nuclear translocation of \{beta\}-catenin. Mol Cell Biol 2009;29:5477-87.

176 Asa SL, Mete O. Multiple endocrine Neoplasia type 1: problems and pitfalls. Pathol Case Rev 2014;19:85-9.

177 Lodish M. Multiple endocrine neoplasia type 2. Front Horm Res 2013;41:16-29.

178 Stratakis CA. Endocrine tumor syndromes and their genetics. Karger Medical and Scientific Publishers, 2013.

179 Carpten JD, Robbins CM, Villablanca A, et al. HRPT2, encoding parafibromin, is mutated in hyperparathyroidism-jaw tumor syndrome. Nat Genet 2002;32:676-80.

180 Brachet C, Boros E, Tenoutasse S, et al. Association of parathyroid adenoma and familial hypocalciuric hypercalcaemia in a teenager. Eur I Endocrinol Eur Fed Endocr Soc 2009:161:207-10.

181 Burski K, Torjussen B, Paulsen AQ, et al. Parathyroid adenoma in a subject with familial hypocalciuric hypercalcemia: coincidence or causality? I Clin Endocrinol Metab 2002:87:1015-16.

182 Thorgeirsson U, Costa J, Marx SJ. The parathyroid glands in familial hypocalciuric hypercalcemia. Hum Pathol 1981;12:229-37.

183 Law WM, Carney JA, Heath H. Parathyroid glands in familial benign hypercalcemia (familial hypocalciuric hypercalcemia). Am J Med 1984;76:1021-6.

184 Carling T, Szabo E, Bai M, et al. Familial hypercalcemia and hypercalciuria caused by a novel mutation in the cytoplasmic tail of the calcium receptor. I Clin Endocrinol Metab 2000;85:2042-7.

185 Nesbit MA, Hannan FM, Howles SA, et al. Mutations affecting G-protein subunit $\alpha 11$ in hypercalcemia and hypocalcemia. N Engl J Med 2013;368:2476-86.

186 Cromer MK, Starker LF, Choi M, et al. Identification of somatic mutations in parathyroid tumors using whole-exome sequencing. I Clin Endocrinol Metab 2012;97:E1774-81.

187 Newey PJ, Nesbit MA, Rimmer AJ, et al. Whole-exome sequencing studies of nonhereditary (Sporadic) parathyroid adenomas. J Clin Endocrinol Metab 2012;97: E1995-2005.

188 Balogh K, Patócs A, Hunyady L, et al. Menin dynamics and functional insight: take your partners. Mol Cell Endocrinol 2010;326:80-4.

189 Heppner C, Kester MB, Agarwal SK, et al. Somatic mutation of the MEN1 gene in parathyroid tumours. Nat Genet 1997;16:375-8.

190 Bergman L, Boothroyd C, Palmer J, et al. Identification of somatic mutations of the MEN1 gene in sporadic endocrine tumours. Br J Cancer 2000;83:1003-8.

191 Palanisamy N, Imanishi Y, Rao PH, et al. Novel chromosomal abnormalities identified by comparative genomic hybridization in parathyroid adenomas. I Clin Endocrinol Metab 1998;83:1766-70. 
192 Hsi ED, Zukerberg LR, Yang WI, et al. Cyclin D1/PRAD1 expression in parathyroid adenomas: an immunohistochemical study. J Clin Endocrinol Metab 1996;81:1736-9.

193 Vasef MA, Brynes RK, Sturm M. Expression of cyclin D1 in parathyroid carcinomas, adenomas, and hyperplasias: a paraffin immunohistochemical study. Mod Pathol 1999;12:412-16.

194 Imanishi Y, Hosokawa Y, Yoshimoto K, et al. Primary hyperparathyroidism caused by parathyroid-targeted overexpression of cyclin D1 in transgenic mice. J Clin Invest 2001;107:1093-102

195 Hemmer S, Wasenius V-M, Haglund C, et al. Deletion of 11q23 and Cyclin D1 overexpression are frequent aberrations in parathyroid adenomas. Am J Pathol 2001;158:1355-62.

196 Zhao L, Sun L, Liu D, et al. Copy number variation in CCND1 gene is implicated in the pathogenesis of sporadic parathyroid carcinoma. World J Surg 2014;38:1730-7.

197 Costa-Guda J, Marinoni I, Molatore S, et al. Somatic mutation and germline sequence abnormalities in CDKN1B, encoding p27Kip1, in sporadic parathyroid adenomas. J Clin Endocrinol Metab 2011;96:E701-6.

198 Buchwald PC, Åkerström G, Westin G. Reduced p18INK4c, p21CIP1/WAF1 and p27KIP1 mRNA levels in tumours of primary and secondary hyperparathyroidism. Clin Endocrinol (Oxf) 2004;60:389-93.

199 Erickson LA, Jin L, Wollan P, et al. Parathyroid hyperplasia, adenomas, and carcinomas: differential expression of p27Kip1 protein. Am J Surg Pathol 1999;23:288-95.

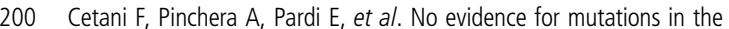
calcium-sensing receptor gene in sporadic parathyroid adenomas. J Bone Miner Res 1999;14:878-82.

201 Carling T, Rastad J, Szabó E, et al. Reduced parathyroid vitamin D receptor messenger ribonucleic acid levels in primary and secondary hyperparathyroidism. J Clin Endocrinol Metab 2000;85:2000-3.

202 Yano S, Sugimoto T, Tsukamoto T, et al. Decrease in vitamin D receptor and calcium-sensing receptor in highly proliferative parathyroid adenomas. Eur J Endocrinol Eur Fed Endocr Soc 2003;148:403-11.

203 Varshney S, Bhadada SK, Saikia UN, et al. Simultaneous expression analysis of vitamin D receptor, calcium-sensing receptor, cyclin D1, and PTH in symptomatic primary hyperparathyroidism in Asian Indians. Eur J Endocrinol Eur Fed Endocr Soc 2013;169:109-16.

204 Farnebo F, Enberg U, Grimelius L, et al. Tumor-specific decreased expression of calcium sensing receptor messenger ribonucleic acid in sporadic primary hyperparathyroidism. J Clin Endocrinol Metab 1997:82:3481-6.

205 Sulaiman L, Juhlin CC, Nilsson I-L, et al. Global and gene-specific promoter methylation analysis in primary hyperparathyroidism. Epigenetics 2013;8:646-55.

206 Soong C-P, Arnold A. Recurrent ZFX mutations in human sporadic parathyroid adenomas. Oncoscience 2014;1:360-6.

207 Arnold A, Soong C-P. New role for ZFX in oncogenesis. Cell Cycle 2014;13:3465-6.

208 Svedlund J, Barazeghi E, Stålberg P, et al. The histone methyltransferase EZH2, an oncogene common to benign and malignant parathyroid tumors. Endocr Relat Cancer 2014;21:231-9.

209 Björklund P, Lindberg D, Åkerström G, et al. Stabilizing mutation of CTNNB1/ beta-catenin and protein accumulation analyzed in a large series of parathyroid tumors of Swedish patients. Mol Cancer 2008;7:1-8.

210 Starker LF, Svedlund J, Udelsman R, et al. The DNA methylome of benign and malignant parathyroid tumors. Genes Chromosomes Cancer 2011;50:735-45.

211 Verdelli C, Forno I, Vaira V, et al. MicroRNA deregulation in parathyroid tumours suggests an embryonic signature. J Endocrinol Invest 2015;38:383-8.

212 Verdelli C, Forno I, Vaira V, et al. Epigenetic alterations in human parathyroid tumors. Endocrine 2015;49:324-32.

213 Svedlund J, Koskinen Edblom S, Marquez VE, et al. Hypermethylated in cancer 1 (HIC1), a tumor suppressor gene epigenetically deregulated in hyperparathyroid tumors by histone H3 lysine modification. J Clin Endocrinol Metab 2012;97: E1307-15.

214 Klein EA, Assoian RK. Transcriptional regulation of the cyclin D1 gene at a glance. J Cell Sci 2008;121(Pt 23):3853-7.

215 Shtutman M, Zhurinsky J, Simcha I, et al. The cyclin D1 gene is a target of the beta-catenin/LEF-1 pathway. Proc Natl Acad Sci USA 1999;96:5522-7.

216 Svedlund J, Aurén $M$, Sundström $M$, et al. Aberrant WNT/B-catenin signaling in parathyroid carcinoma. Mol Cancer 2010;9:294.

217 Carling T, Du Y, Fang W, et al. Intragenic allelic loss and promote hypermethylation of the RIZ1 tumor suppressor gene in parathyroid tumors and pheochromocytomas. Surgery 2003;134:932-9; discussion 939-940.
218 Donninger H, Vos MD, Clark GJ. The RASSF1A tumor suppressor. J Cell Sci 2007;120:3163-72.

219 Juhlin CC, Kiss NB, Villablanca A, et al. Frequent promoter hypermethylation of the APC and RASSF1A tumour suppressors in parathyroid tumours. PLOS ONE 2010;5:e9472

220 Shivakumar L, Minna J, Sakamaki T, et al. The RASSF1A tumor suppressor blocks cell cycle progression and inhibits cyclin D1 accumulation. Mol Cell Biol 2002;22:4309-18.

221 Tan M-H, Morrison C, Wang P, et al. Loss of parafibromin immunoreactivity is a distinguishing feature of parathyroid carcinoma. Clin Cancer Res 2004; 10:6629-37.

222 Gill AJ, Clarkson A, Gimm 0, et al. Loss of nuclear expression of parafibromin distinguishes parathyroid carcinomas and hyperparathyroidism-jaw tumor (HPT-JT) syndrome-related adenomas from sporadic parathyroid adenomas and hyperplasias. Am J Surg Pathol 2006;30:1140-9.

223 Howell VM, Gill A, Clarkson A, et al. Accuracy of combined protein gene product 9.5 and parafibromin markers for immunohistochemical diagnosis of parathyroid carcinoma. J Clin Endocrinol Metab 2009;94:434-41.

224 Shattuck TM, Välimäki S, Obara T, et al. Somatic and germ-line mutations of the HRPT2 gene in sporadic parathyroid carcinoma. N Engl J Med 2003;349:1722-9.

225 Haven CJ, van Puijenbroek M, Tan MH, et al. Identification of MEN1 and HRPT2 somatic mutations in paraffin-embedded (sporadic) parathyroid carcinomas. Clin Endocrinol (Oxf) 2007;67:370-6.

226 Yu W, McPherson JR, Stevenson M, et al. Whole-exome sequencing studies of parathyroid carcinomas reveal novel PRUNE2 mutations, distinctive mutational spectra related to APOBEC-catalyzed DNA mutagenesis and mutational enrichment in kinases associated with cell migration and invasion. J Clin Endocrinol Metab 2015;100:E360-4.

227 Kasaian K, Wiseman SM, Thiessen N, et al. Complete genomic landscape of a recurring sporadic parathyroid carcinoma. J Pathol 2013;230:249-60.

228 Alvelos MI, Vinagre J, Fonseca E, et al. MEN1 intragenic deletions may represent the most prevalent somatic event in sporadic primary hyperparathyroidism. Eur $J$ Endocrinol 2013;168:119-28.

229 Alvelos MI, Mendes M, Soares P. Molecular Alterations in Sporadic Primary Hyperparathyroidism. Genet Res Int 2011;2011:e275802.

230 Haglund $\mathrm{F}$, Juhlin CC, Brown T, et al. TERT promoter mutations are rare in parathyroid tumors. Endocr Relat Cancer 2015;22:L9-11.

231 Marcocci C, Bollerslev J, Khan AA, et al. medical management of primary hyperparathyroidism: proceedings of the fourth international workshop on the management of asymptomatic primary hyperparathyroidism. J Clin Endocrinol Metab 2014;99:3607-18.

232 Cozzolino M, Tomlinson J, Walsh L, et al. Emerging drugs for secondary hyperparathyroidism. Expert Opin Emerg Drugs 2015;20:197-208.

233 Punch JD, Thompson NW, Merion RM. Subtotal parathyroidectomy in dialysis-dependent and post-renal transplant patients. A 25 -year single-center experience. Arch Surg Chic III 1960 1995;130:538-42; discussion 542-543.

234 Schlosser K, Zielke A, Rothmund M. Medical and surgical treatment for secondary and tertiary hyperparathyroidism. Scand J Surg 2004;93:288-97.

235 Singh Ospina N, Thompson GB, Lee RA, et al. Safety and efficacy of percutaneous parathyroid ethanol ablation in patients with recurrent primary hyperparathyroidism and multiple endocrine neoplasia type 1. J Clin Endocrinol Metab 2015;100:E87-90.

236 Alherabi AZ, Marglani OA, Alfiky MG, et al. Percutaneous ultrasound-guided alcohol ablation of solitary parathyroid adenoma in a patient with primary hyperparathyroidism. Am J Otolaryngol Published Online First: 14 Apr 2015 doi:10.1016/i.amjoto.2015.04.006

237 Fountas A, Andrikoula M, Giotaki Z, et al. The emerging role of denosumab in the long term management of parathyroid carcinoma-related refractory Hypercalcemia. Endocr Pract 2015;21:468-73.

238 Vellanki $P$, Lange $K$, Elaraj $D$, et al. Denosumab for management of parathyroid carcinoma-mediated hypercalcemia. J Clin Endocrinol Metab 2014;99:387-90.

239 Peacock M, Bilezikian JP, Bolognese MA, et al. Cinacalcet $\mathrm{HCl}$ reduces hypercalcemia in primary hyperparathyroidism across a wide spectrum of disease severity. J Clin Endocrinol Metab 2011;96:E9-18.

240 Duntas LH, Stathatos N. Cinacalcet as alternative treatment for primary hyperparathyroidism: achievements and prospects. Endocrine 2011;39: 199-204.

241 Habib Z, Kabaker A, Camacho P. Sporadic primary hyperparathyroidism: medical and surgical updates. Expert Rev Endocrinol Metab 2013;9:31-44.

242 Apel RL, Asa SL. The parathyroid glands. In: LiVolsi V, Asa SL, eds. Endocrine pathology. Philadelphia: Churchill Livingstone, 2002:103-47. 